\title{
Identifying avifauna and the presence time of migratory birds at a university campus in the southwest of Iran
}

\author{
Kamran Almasieh* and Mohammad Moazami \\ Department of Nature Engineering, Agricultural Sciences and Natural Resources University of Khuzestan, \\ 6341773637 Mollasani, Iran \\ *Corresponding author ${ }^{\star}$ : almasieh@asnrukh.ac.ir
}

Received: 5 April 2020

Accepted: 12 May 2020

Published online: 20 May 2020

\begin{abstract}
In wildlife management, sufficient information about fauna is vital for conservation of species and their habitats. Furthermore, the number of bird species in a habitat can represent an index of habitat quality. Therefore, this study was carried out to identify bird fauna on a university campus (i.e. Agricultural Sciences and Natural Resources University of Khuzestan, abbreviated as ASNRUKH) in the southwest of Iran in order to determine the number of bird species, the day of their arrival, and the presence time of migratory birds on campus. Field survey and identification of birds were carried out in the study area, with an area of 72.9 ha, using binoculars from June 2017 to May 2018 in linear transects spaced 20 meters apart. We identified 62 bird species, including nine raptors, which is equal to $11.25 \%$ of bird species in Iran. In total, 19 residents, five summer visitors, 21 winter visitors and 17 passing migratory birds were identified. The lowest co-occurrence number of species (21-25) was observed from middle June to early October and the maximum number of concurrent species (38-41) were recorded from late November to early January. The Western Barn Owl Tyto alba was the only resident raptor, which is part of an integrated pest management system throughout the year. ASNRUKH's long-established persistent favorable microclimate supports both resident and migratory birds. In addition, the study area provides food and safety for migratory birds from across the globe as a stopover site.
\end{abstract}

Key words: ASNRUKH, bird species, day of arrival, raptors, stopover site

\section{Introduction}

Birds (class Aves) are endothermic vertebrates with feather-covered bodies and toothless beaks, which are distributed all around the world (Kaboli et al., 2016). Barrowclough et al. (2016) estimated the highest number of bird species in the world around 18,000 species. The International Union for Conservation of Nature (IUCN) identified 11,126 bird species in its Red List so far, of which 1,492 (13\% of birds) are threatened (224 species are critically endangered [CR], 469 endangered [EN] and 799 vulnerable [VU]) (IUCN, 2019). Birds are classified into 36 orders, with Passeriformes containing the largest number of species $(6,648$ species) and Opisthocomiformes and Leptosomiformes containing the smallest number of species (one species in each order) (IUCN, 2019). 
Iran is a vast country in the Palearctic realm, located on the border of the Oriental and Ethiopian realms, with a variety of topographical and climatic regions because Iran's biodiversity is affected by these three realms (Coad and Vilenkin, 2004). A total of 551 bird species in 26 orders and 80 families have been identified in Iran (Khaleghizadeh et al., 2017; Ashoori, 2018); approximately equal to the total number of bird species in Europe (Kaboli et al., 2016). Furthermore, the country has the highest number of migratory bird species in the Middle East (Kirby et al., 2008; Nourani et al., 2014). In addition, 62 raptors (birds of prey) have been identified from Iran (Khaleghizadeh et al., 2017).

Raptors are members of the orders Accipitriformes, Falconiformes and Strigiformes. Raptors are apex predators and play essential roles in ecosystems (Donazar et al., 2016; Khaleghizadeh and Anuar, 2019). They offer indicators of habitat quality because of their sensitivity to human activities (e.g. environmental pollution). Therefore, conservation biologists pay special attention to raptors in their conservation plans (Rodríguez - Estrella et al., 1998). Raptors are also considered as surrogates of biodiversity in the landscape when prioritizing areas for protection (Burgas et al., 2014).

In wildlife management, sufficient information about fauna is necessary for conservation of species and their habitats (Ayodeji and Kilishi, 2019; Vilkov, 2020); basically, the number of bird species in a habitat can be an index of habitat quality. Therefore, this study was aimed at identifying bird fauna on a university campus in the southwest of Iran to detect the number of bird species, including raptors, and the presence time of any migratory birds.

\section{Material and Methods}

\section{Study area}

Agricultural Sciences and Natural Resources University of Khuzestan (hereafter ASNRUKH) $\left(31^{\circ} 35^{\prime} 51.45^{\prime \prime} \mathrm{N}\right.$ and $48^{\circ} 533^{\prime} 3.84^{\prime \prime} \mathrm{E}$, with an area of $\left.72.9 \mathrm{ha}\right)$ is located in the center of Khuzestan Province, southwestern Iran (Fig. 1). The area experiences high temperatures in summer averaging $\sim 37^{\circ} \mathrm{C}$ with a maximum of $50{ }^{\circ} \mathrm{C}$, and mild winters averaging $\sim 17{ }^{\circ} \mathrm{C}$ and a minimum of $5{ }^{\circ} \mathrm{C}$ (IRIMO, 2017). ASNRUKH is almost six decades old, and the presence of green spaces with large old trees (e.g. Lebbek Tree Albizia lebbeck, Pipal Tree Ficus religiosa, Christ's Thorn Jujube Ziziphus spina-christi and Eucalyptus Eucalyptus camaldulensis) and palm species (e.g. Date Palm Phoenix dactylifera, Canary Island Date Palm Phoenix canariensis and Washington Palm Washingtonia filifera) attracts many bird species. The Karun River, the longest river in Iran, is located to the west of ASNRUKH (Fig. 1) and its riparian habitats attract many bird species, especially waders (Behrouzi-Rad et al., 2015). Southern Iran, where Khuzestan Province and the study area are located, is affected by both the Oriental and Ethiopian zoogeographical realms, which has led to its high biodiversity (Coad and Vilenkin, 2004).

\section{Data collection and species identification}

A field survey was carried out from June 2017 to May 2018, once every two weekends from sunrise for four hours; in addition, several field surveys were carried out randomly for three hours before sundown. As feeding activity in birds generally occurs in early morning and late afternoon, birds are known as species with a bimodal activity pattern (Reyes-Arriagada et al., 2015). Thus, these intervals were selected as the two best times for bird observation (McNamara et al., 1994). Linear transects set 20 meters apart were surveyed at ASNRUKH and bird identification was carried out with direct observation by one person using binoculars (Steiner, model Al-Saghar II 8x30, Germany). In addition, photos of birds were captured with 
a digital camera (Canon SX60 with 65x magnification, Japan). Species were identified using Birds of the Middle East (Porter and Aspinall, 2010), Collins Bird Guide (Svensson et al., 2010), and Atlas of Birds of Iran (Kaboli et al., 2016). To ensure correct identifications, photos of birds were sent to expert ornithologists to check our identifications.

For the taxonomy of species, we used the IOC World Bird List (Gill and Donsker, 2019). We checked the conservation status of each identified species in Iran according to the report by Iran's Department of Environment (DOE) (DOE, 2019) and the global status according to the IUCN Red List of threatened species (IUCN, 2019). We looked for migratory birds every two weeks and their day of arrival and presence time were recorded. As the authors were residents at ASNRUKH, the day of arrival was also recorded on dates other than the biweekly observation. We also relied on bird calls for detecting their arrival. For each species, we determined whether the species was a resident, summer visitor, winter visitor, or passing migrant.

Finally, we overlaid the number of days when species inhabited the study area to determine the interval when the highest number of bird species were present. We also performed the above-mentioned analysis for raptor species and protected species separately to compare them with other species in the study area. The presence time of bird species in the study area was illustrated using Excel software (version 2013).

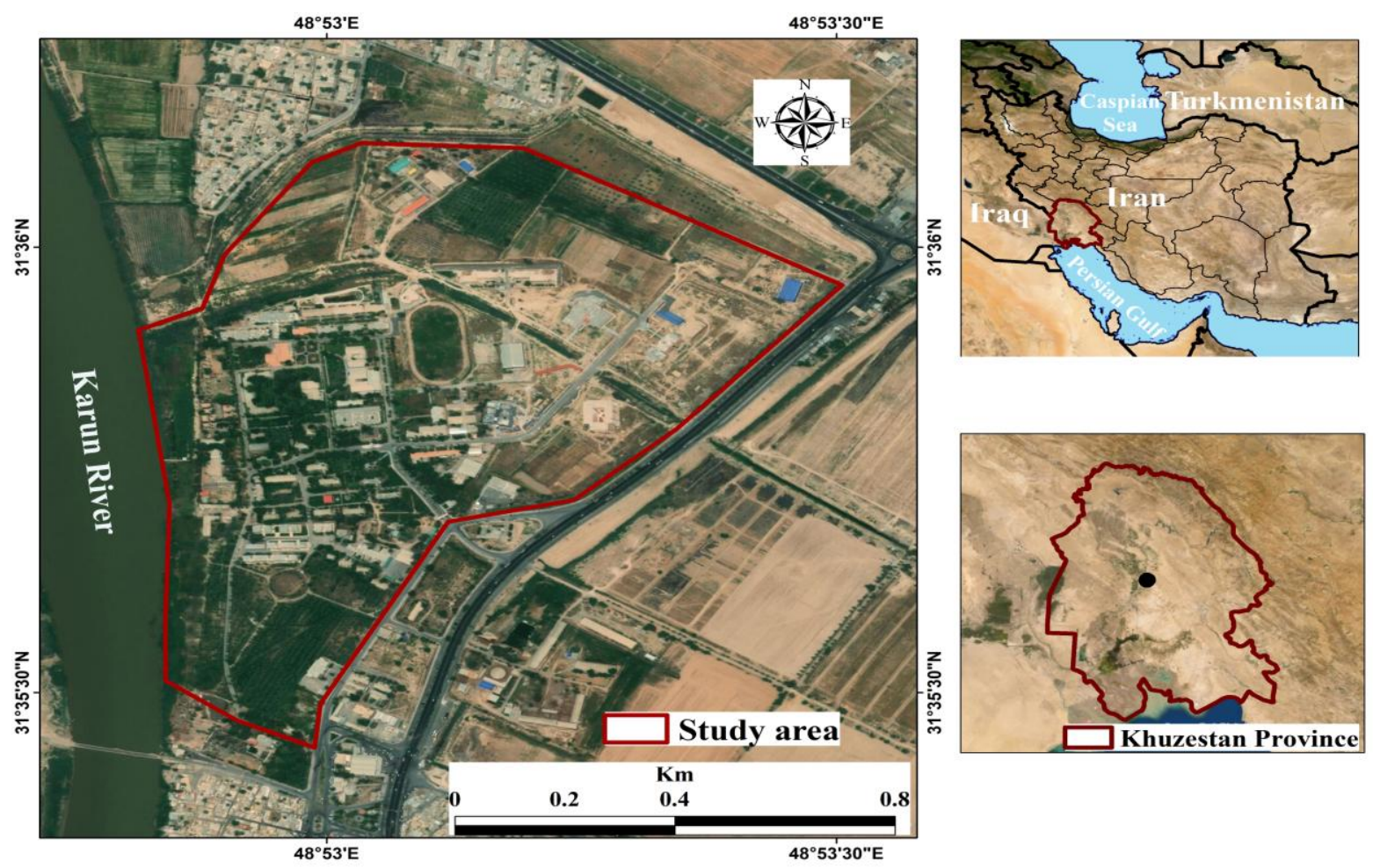

Figure 1: Location of the study area in Khuzestan Province and Iran. Map created in ArcGIS (version 10.3) with Imagery Basemap.

\section{Results}

We recorded 62 bird species belonging to 32 families and 12 orders in the study area, which is equal to $11.25 \%$ of bird species in Iran (Table 1). In total, 19 residents, 5 summer visitors, 21 winter visitors and 17 passing migratory birds were identified in the study area (Table 1). The largest number of species in the study area belonged to the order Passeriformes ( 32 species) and family Accipitridae (7 species) (Table 1). 


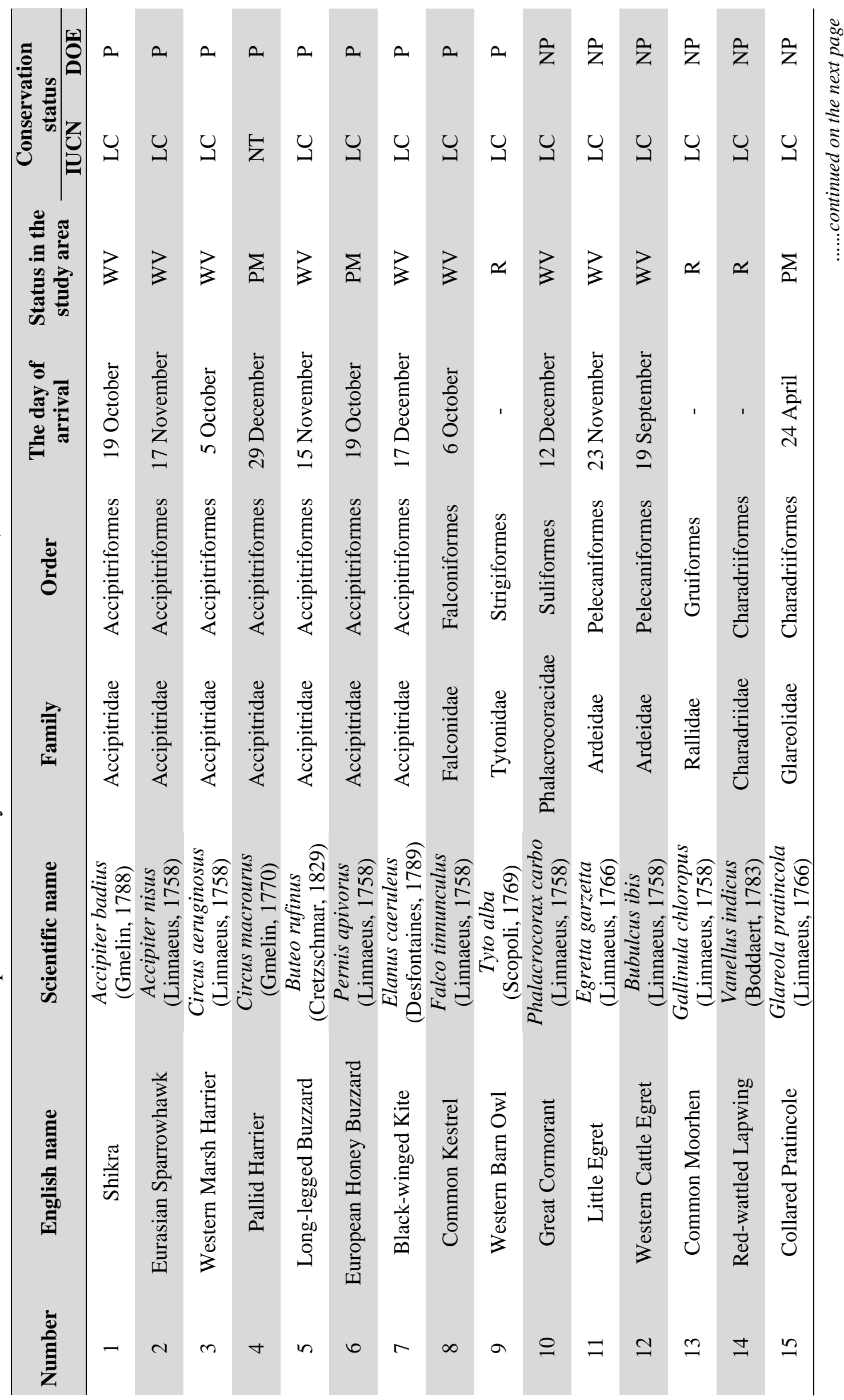




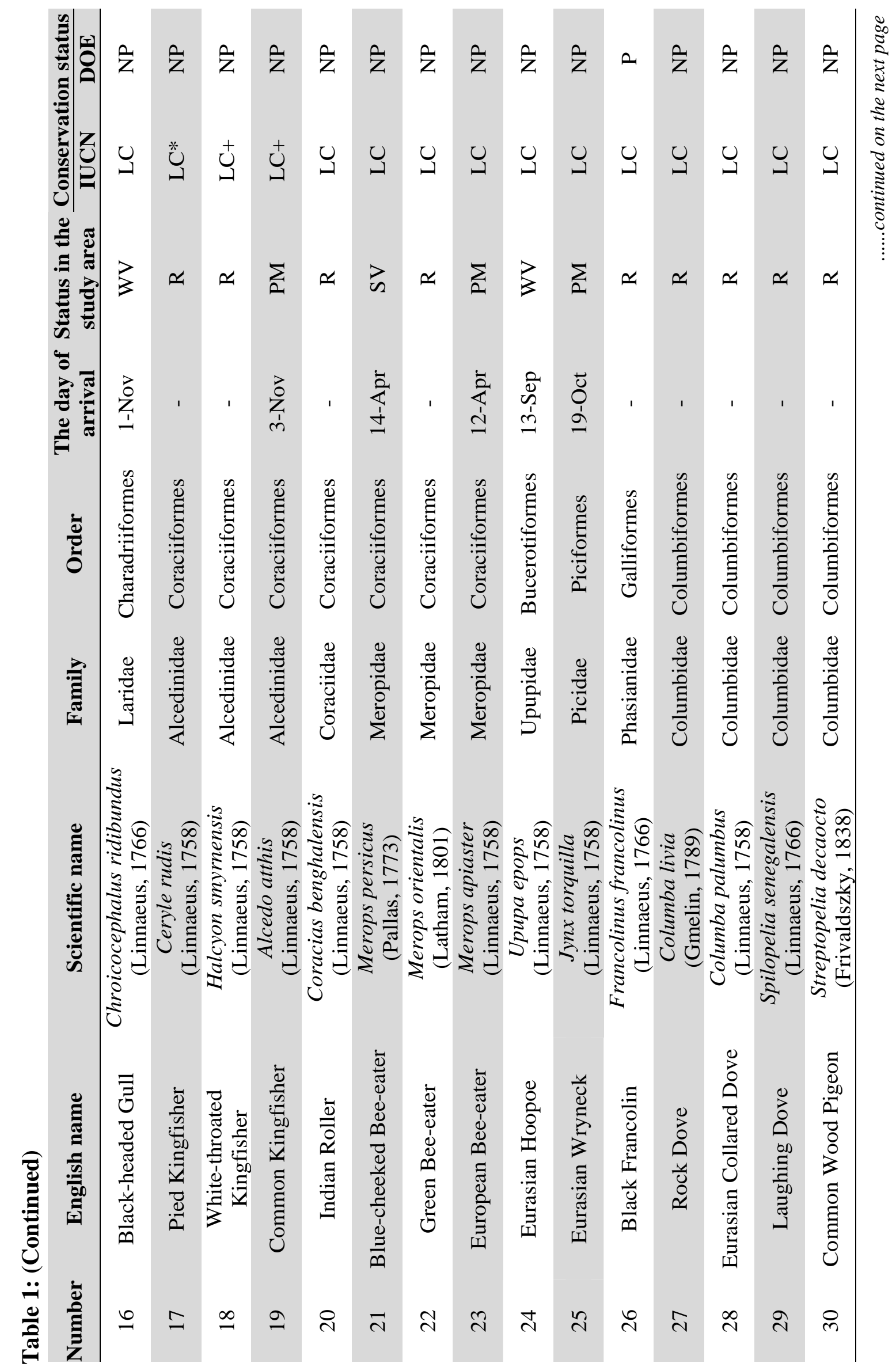




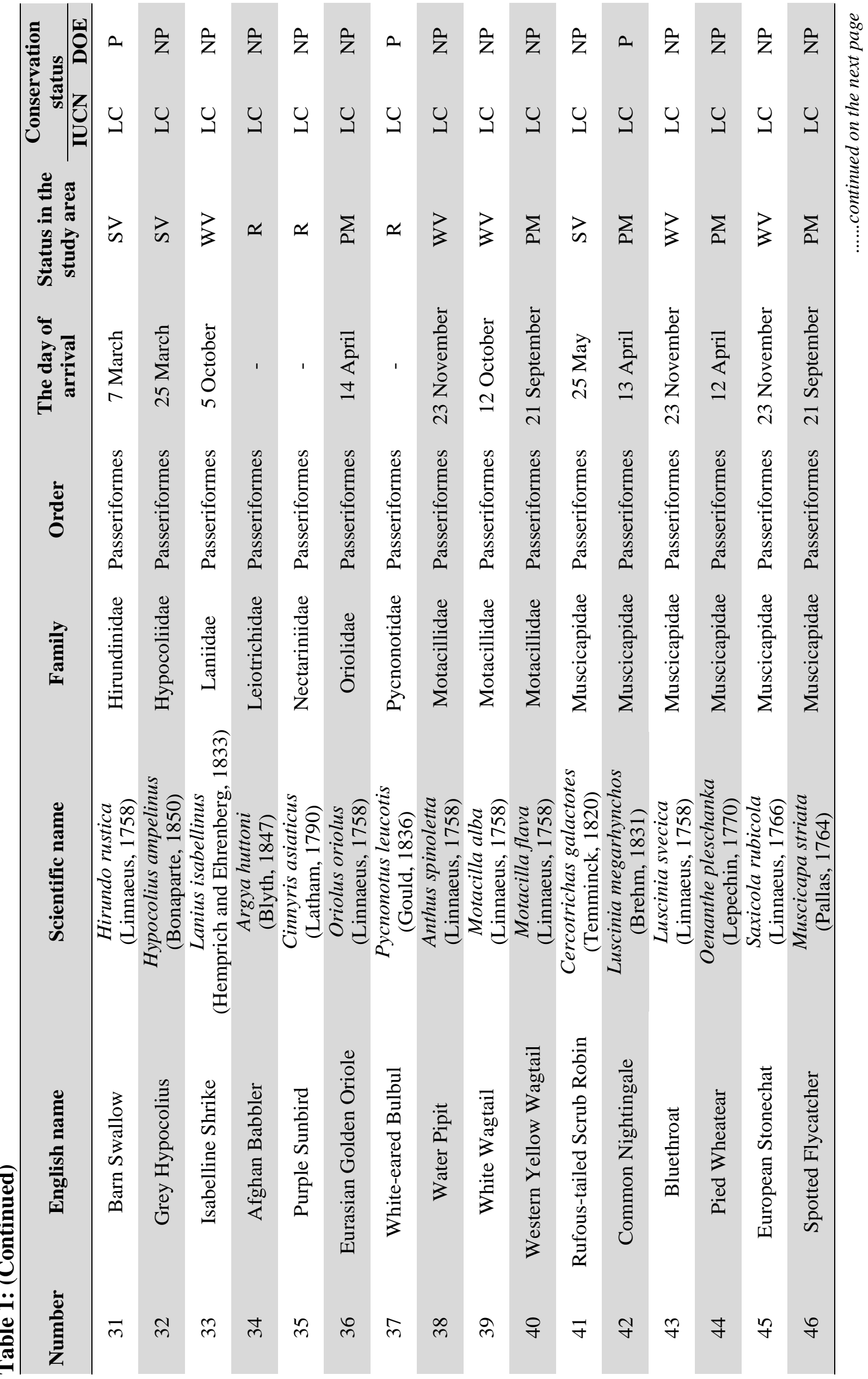




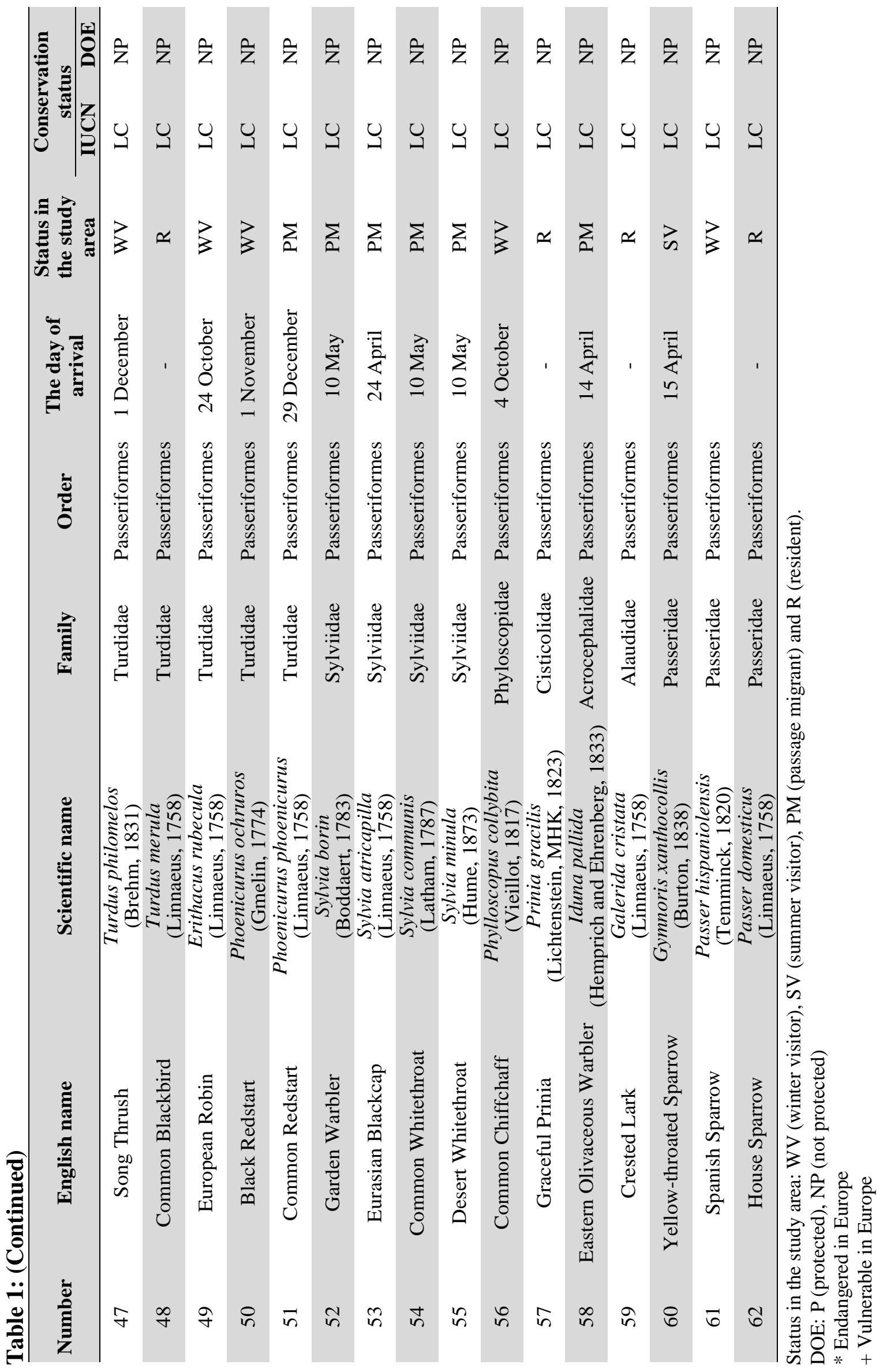


We took photos of all observed species except the Black Francolin Francolinus francolinus (Linnaeus), which was observed but not photographed (Appendix 1). Two dead birds were found in the study area (the Common Moorhen Gallinula chloropus (Linnaeus) and Eurasian Blackcap Sylvia atricapilla (Linnaeus). In addition, five species, namely the Pallid Harrier Circus macrourus (Gmelin), Common Kingfisher Alcedo atthis (Linnaeus), Pied Wheatear Oenanthe pleschanka (Lepechin), Common Whitethroat Sylvia communis (Latham) and Desert Whitethroat Sylvia minula (Hume) were observed only once (December $29^{\text {th }}$, November $3^{\text {rd }}$, April $12^{\text {th }}$, May $10^{\text {th }}$ and May $10^{\text {th }}$, respectively). Therefore, the single instance when the species (alive or dead) was observed is recorded as its time of presence in the study area (except G. chloropus, which is resident in the study area).

According to the IUCN Red List, all identified species are currently categorized as least concern (LC) (three species are threatened only in Europe), except for C. macrourus, which is near threatened (NT). On the other hand, 13 species, including nine raptors, are categorized as nationally protected species according to the DOE criteria. The raptors belong to three orders (seven species from Accipitriformes, one species from Falconiformes and one species from Strigiformes) (Table 1). Six raptors were winter visitors and two raptors were passing migrants. The Western Barn Owl Tyto alba (Scopoli) was the only resident raptor in the study area (Table 1; Fig. 2).

The day of arrival (Table 1) and the time of presence (Fig. 2) for each bird species was recorded. The minimum concurrent presence of 21-25 species was recorded from middle June to early October and the maximum concurrent presence of 38-41 species was detected from late November to early January (Fig. 2). Overall, the number of bird species in the study area reached a peak in November and December, and then a downward trend began, finally reaching its minimum in July and September. A maximum of 6-7 raptor species was observed from middle November to early January at ASNRUKH. This number fell to one species ( $T$. $a l b a$ ) from late February to early October. Regarding protected species, the presence of a maximum of 8-9 species was detected at ASNRUKH from middle November to early January. The minimum number of protected species (three species) was recorded from middle June to early October (for the exact time of co-occurrence, refer to Table 1 and Fig. 2).

\section{Discussion}

The avifauna of the study area supported different birds with varying global distributions; from cosmopolitan species (e.g. the Barn Swallow Hirundo rustica (Linnaeus) and House Sparrow Passer domesticus (Linnaeus), Palearctic species (e.g. the European Stonechat Saxicola rubicola (Linnaeus) and European Robin Erithacus rubecula (Linnaeus), Oriental species (e.g. the Red-wattled Lapwing Vanellus indicus (Boddaert), White-throated Kingfisher Halcyon smyrnensis (Linnaeus), Green Bee-eater Merops orientalis (Latham) and Afghan Babbler Argya huttoni (Blyth), Palearctic-African species (e.g. the European Honey Buzzard Pernis apivorus (Linnaeus) and Collared Pratincole Glareola pratincola (Linnaeus), to Oriental-Ethiopian species (e.g. the Shikra Accipiter badius (Gmelin), Black-winged Kite Elanus caeruleus (Desfontaines) and Pied Kingfisher Ceryle rudis (Linnaeus) (Khaleghizadeh et al., 2017; IUCN, 2019). Therefore, despite its small size, the study area is able to support avifauna from different parts of the world.

Regarding the limitations of this research, we tried to monitor all parts of the study area in a year, however, it is possible that some birds, especially passing migratory birds, might not have been detected. In a few cases, we observed a species only once (alive or dead), which forced us to report the day of observation as its time of presence. All such species were passing migratory birds with limited presence at ASNRUKH. 


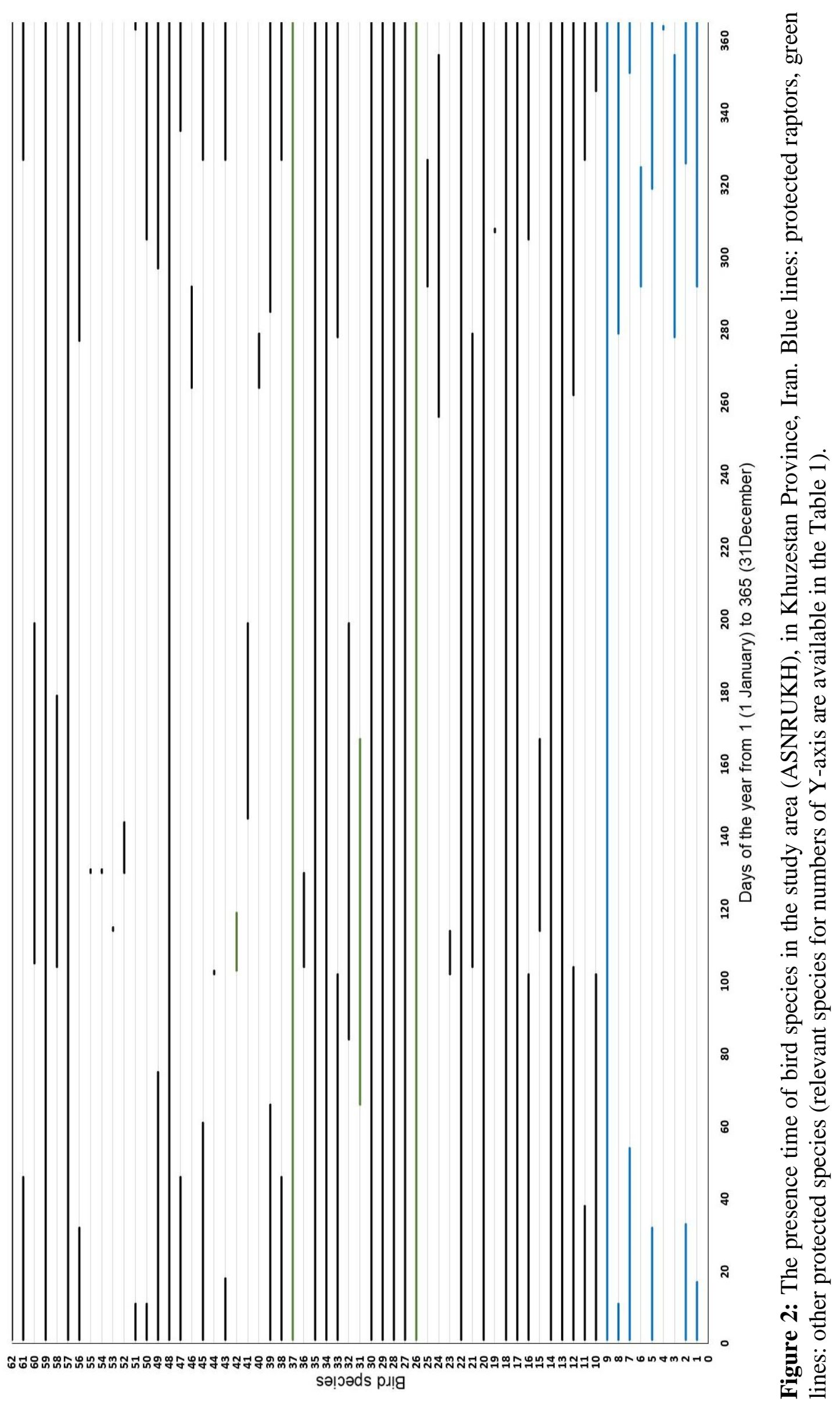


We tried to determine the day of arrival and time of presence for the migratory bird species, however, presence time might not be precise for some species in the study area. Furthermore, longer-term monitoring is suggested to determine the arrival time of migratory species and the duration of their presence in the study area. We will try to expand our research in future years in order to detect the changes in date of arrival for migratory birds due to the possible impact of climate change (Wilson, 2013; Kullberg et al., 2015). In the Palearctic region, including the study area, many migratory bird species will likely advance their arrival to the breeding region because of climate change and global warming (Newton, 2010).

The study area reported nine raptors, including T. alba. This raptor has an extensive global distribution and is a well-known predator of rodents, providing an economic service to farmers by controlling the rodent population in farmlands (Marti et al., 2005; Kan et al., 2013; Kross et al., 2016). Tyto alba is nocturnal (Taylor, 1994; Abramsky et al., 1996) and can hunt nocturnal rodents in the farmlands within the study area. In addition, it is a resident species and can be a part of integrated pest management throughout the year in the farmlands of the study area.

Recently, populations of migratory species have declined globally (Wilcove and Wikelski, 2008). This phenomenon is partly caused by the declining number of stopover sites (Vickery et al., 2014; Howard et al., 2018). Long flights during migration exhaust a considerable portion of a birds' energy reserves (Hutto, 1998); therefore, stopover sites such as ASNRUKH provide food and safety for the passing migratory birds (e.g. P. apivorus) whose core habitats in the Middle East have declined or are threatened (Evans, 1994; Khaleghizadeh et al., 2017). In addition, ASNRUKH was a suitable and safe habitat for resident birds, like $F$. francolinus (a protected species and the only species from Galliformes in the study area). Francolinus francolinus is experiencing similar degrading conditions as $P$. apivorus in the Middle East (Evans, 1994; Khaleghizadeh et al., 2017).

Given the local mild winters, the study area can attract many winter visiting birds; consequently, the number of bird species in the study area reaches the maximum in the colder months. The same is true for raptors and other protected species. Nevertheless, because of its very hot summers, few summer visiting birds choose the study area. ASNRUKH's longestablished persistent microclimate, riparian habitats and availability of different foods in all seasons supports resident and migratory birds, including raptors from around the world.

\section{Acknowledgments}

We thank Mohammad Safrang and other Iranian ornithologists for helping us to identify birds. We are also grateful to Dr. Kazem Negaresh for identifying plant species on the university campus. We appreciate the anonymous reviewers for their careful reading of our manuscript and their valuable comments and suggestions, and Hadi Amini for donating the Black Francolin photo. This work was supported by the Research and Technology of Agricultural Sciences and Natural Resources University of Khuzestan [Project number 961/17].

\section{References}

Abramsky, Z., Strauss, E., Subach, A., Kotler, B. P. and Riechman, A. (1996). The effect of barn owls (Tyto alba) on the activity and microhabitat selection of Gerbillus allenbyi and G. pyramidum. Oecologia, 105 (3): 313-319. https://doi.org/10.1007/BF00328733

Ashoori, A. (2018). The birds of Bujagh national park, Iran, 2004-2016. Sandgrouse, 40: $144-156$. 
Ayodeji, A. O. and Kilishi, H. S. (2019). Avifauna species diversity and abundance in Kainji Lake National Park, Niger State, Nigeria. Journal of Wildlife and Biodiversity, 3 (4): 1626. https://doi.org/10.22120/jwb.2019.104859.1058

Barrowclough, G. F., Cracraft, J., Klicka, J. and Zink, R. M. (2016). How many kinds of birds are there and why does it matter? PLoS ONE, 11 (11): e0166307. https://doi.org/10.1371/journal.pone.0166307

Behrouzi-Rad, B., Maktabi, P. and Jafarnejad, A. (2015). Density and diversity of water birds and terrestrial birds at islands in Karoon River in Ahvaz City. Coastal and Marine Research, 3 (1): 1-9. https://doi.org/10.12966/cmr.01.01.2015

Burgas, D., Byholm, P. and Parkkima, T. (2014). Raptors as surrogates of biodiversity along a landscape gradient. Journal of Applied Ecology, 51 (3): 786-794. https://doi.org/10.1111/1365-2664.12229

Coad, B. W. and Vilenkin, B. Y. (2004). Co-occurrence and zoogeography of the freshwater fishes of Iran. Zoology in the Middle East, 31 (1): 53-62. https://doi.org/10.1080/09397140.2004.10638022

DOE (Department of the Environment of Iran) (2019). Department of the Environment of Iran. www.doe.ir (Accessed 1 October 2019).

Donazar, J. A., Cortes-Avizanda, A., Fargallo, J. A., Margalida, A., Moleon, M., MoralesReyes, Z., Moreno-Opo, R., Perez-Garcia, J. M., Sanchez-Zapata, J. A., Zuberogoitia, I. and Serrano, D. (2016). Roles of raptors in a changing world: from flagships to providers of key ecosystem services. Ardeola, 63 (1): 181-234. https://doi.org/10.13157/arla.63.1.2016.rp8

Evans, M. I. (1994). Important bird areas in the Middle East. Birdlife Conservation Series, No. 2. Birdlife International, Cambridge, UK. 410 pp.

Gill, F. and Donsker, D. (Eds). (2019). IOC World Bird List (v9.2). https://doi.org/10.14344/IOC.ML.9.2

Howard, C., Stephens, P. A., Tobias, J. A., Sheard, C., Butchart, S. H. M. and Willis, S. G. (2018). Flight range, fuel load and the impact of climate change on the journeys of migrant birds. Proceedings of the Royal Society B: Biological Sciences, 285 (1873): https://doi.org/10.1098/rspb.2017.2329

Hutto, R. L. (1998). On the importance of stopover sites to migrating birds. The Auk, 115 (4): 823-825. https://doi.org/10.2307/4089500

IRIMO (Islamic Republic of Iran Meteorological Organization) (2017). Climate data-base, Iranian cities, from 1993 to 2017. https://www.irimo.ir (Accessed 1 October 2018).

IUCN (International Union for Conservation of Nature) (2019). IUCN Red List of Threatened Species (IUCN, Gland, Switzerland). www.iucnredlist.org (Downloaded on 8 April 2019).

Kaboli, M., Aliabadian, M., Tohidifar, M., Hashemi, A., Musavi, S. B. and Roselaar, C. C. (2016). Atlas of birds of Iran. Iran Department of the Environment, Tehran, Iran. 617 pp.

Kan, I., Motro, Y., Horvitz, N., Kimhi, A., Leshem, Y., Yom-Tov, Y. and Nathan, R. (2013). Agricultural rodent control using barn owls: is it profitable? American Journal of Agricultural Economics, 96 (3): 733-752. https://doi.org/10.1093/ajae/aat097

Khaleghizadeh, A., Roselaar, K., Scott, D. A., Tohidifar, M., Mlíkovský, J., Blair, M. and Kvartalnov, P. (2017). Birds of Iran: Annotated checklist of the species and subspecies. Iranshenasi Publishing, Tehran, Iran. 500 pp. 
Khaleghizadeh, A. and Anuar, S. (2019). Comparative behavioral ecology of the WhiteBellied Sea Eagle and Brahminy Kite (Aves: Accipitriformes) in Northwestern Malaysia. Journal of Animal Diversity, 1 (1): 41-55. https://doi.org/10.29252/JAD.2019.1.1.6

Kirby, J. S., Stattersfield, A. J., Butchart, S. H. M., Evans, M. I., Grimmett, R. F. A., Jones, V. R., O'Sullivan, J., Tucker, G. M. and Newton, I. (2008). Key conservation issues for migratory land- and waterbird species on the world's major flyways. Bird Conservation International, 18: S49-S73. https://doi.org/10.1017/S0959270908000439

Kross, S. M., Bourbour, R. P. and Martinico, B. L. (2016). Agricultural land use, barn owl diet, and vertebrate pest control implications. Agriculture, Ecosystems and Environment, 223: 167-174. https://doi.org/10.1016/j.agee.2016.03.002

Kullberg, C., Fransson, T., Hedlund, J., Jonzen, N., Langvall, O., Nilsson, J. and Bolmgren, K. (2015). Change in spring arrival of migratory birds under an era of climate change, Swedish data from the last 140 years. AMBIO, 44: 69-77. https://doi.org/10.1007/s13280-014-0600-1

Marti, C. D., Alan, F. P. and Bevier, L. R. (2005). Barn owl (Tyto alba). Cornell Lab of Ornithology, Ithaca. http://bna.birds.cornell.edu/bna/species/001

McNamara, J. M., Houston, A. I. and Lima, S. L. (1994). Foraging routines of small birds in winter: a theoretical investigation. Journal of Avian Biology, 25 (4): 287-302. https://doi.org/10.2307/3677276

Newton, I. (2010). The migration ecology of birds. First Edition. Elsevier. 984 pp.

Nourani, E., Kaboli, M. and Collen, B. (2014). An assessment of threats to Anatidae in Iran. $\begin{array}{lllll}\text { Bird Conservation } & \text { International, } & 25 & \text { (2): } & 242-257 .\end{array}$ https://doi.org/10.1017/S0959270914000264

Porter, R. and Aspinall, S. (2010). Birds of the Middle East. Second Edition. Princeton University Press, USA. 384 pp.

Reyes-Arriagada, R., Jiménez, J. E. and Rozzi, R. (2015). Daily patterns of activity of passerine birds in a Magellanic sub-Antarctic forest at Omora Park $\left(55^{\circ} \mathrm{S}\right)$, Cape Horn Biosphere Reserve, Chile. Polar Biology, 38: 401-411. https://doi.org/10.1007/s00300014-1596-5

Rodríguez - Estrella, R., Donázar, J. A. and Hiraldo, F. (1998). Raptors as indicators of environmental change in the scrub habitat of Baja California Sur, Mexico. Conservation Biology, 12 (4): 921-925. https://doi.org/10.1111/j.1523-1739.1998.97044.x

Svensson, L., Mullarney, K., Zetterström, D. And Grant, P. J. (2010). Collins bird guide. Second Edition. Harper Collins Publisher, London. 445 pp.

Taylor, I. (1994). Barn Owls: Predator-prey relationships and conservation. Cambridge University Press, UK. 324 pp.

Vickery, J. A., Ewing, S. R., Smith, K. W., Pain, D. J., Bairlein, F., Skorpilova, J. and Gregory, R. D. (2014). The decline of Afro-Palaearctic migrants and an assessment of potential causes. Ibis, 156 (1): 1-22. https://doi.org/10.1111/ibi.12118

Vilkov, E. (2020). The structure, territorial relationships and ecology of birds in highmountain Daghestan. Journal of Wildlife and Biodiversity, 4 (1): 8-17. http://dx.doi.org/10.22120/jwb.2019.113176.1097

Wilcove, D. S. and Wikelski, M. (2008). Going, going, gone: is animal migration disappearing? PLoS Biology, 6 (7): e188. https://doi.org/10.1371/journal.pbio.0060188

Wilson, W. H. (2013). A deeper statistical examination of arrival dates of migratory breeding birds in relation to global climate change. Biology, 2 (2): 742-754. https://doi.org/10.3390/biology2020742 


\section{Appendix}

Appendix 1: Photos of bird species in the study area (ASNRUKH), (all photos with the exception of photo 26 were taken by the first author).

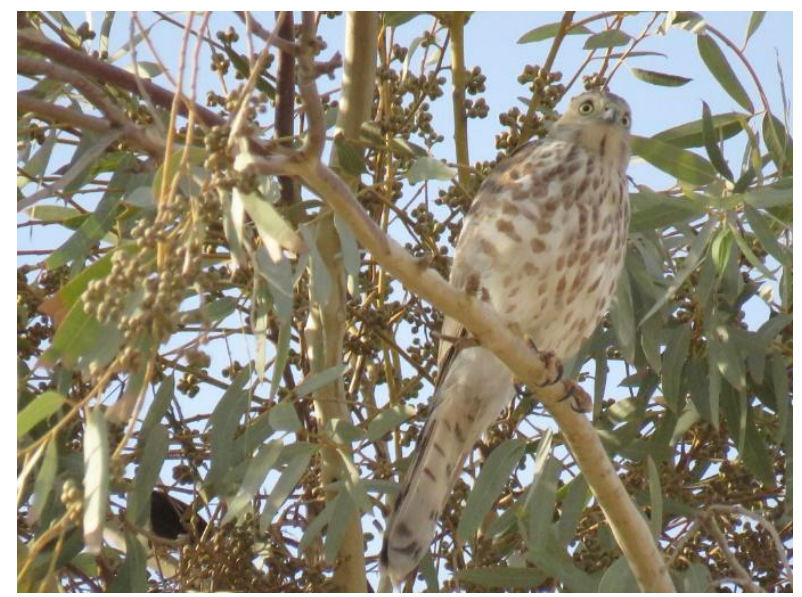

1. Shikra, Accipiter badius

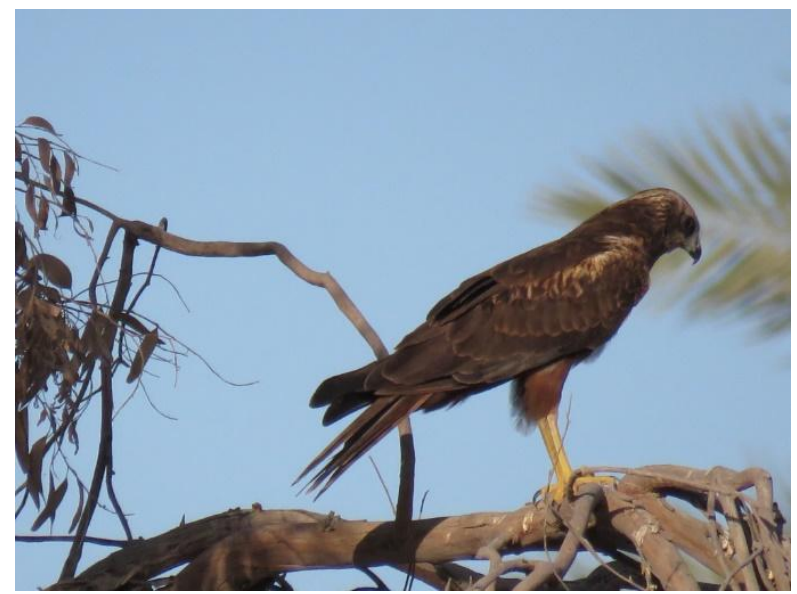

3. Western Marsh Harrier, Circus aeruginosus

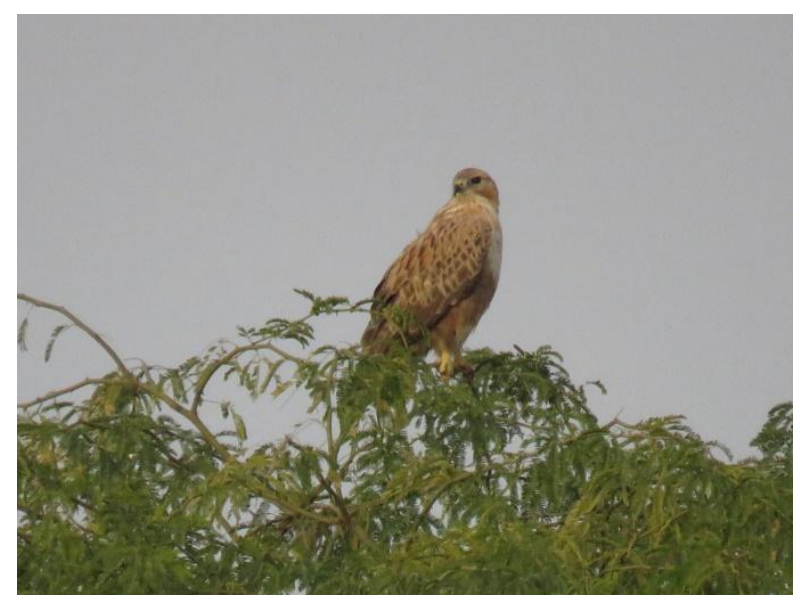

5. Long-legged Buzzard, Buteo rufinus

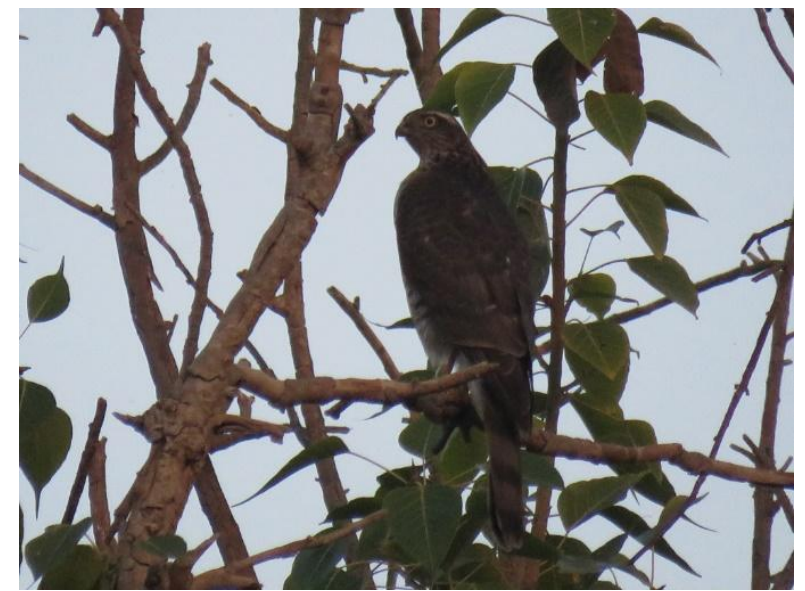

2. Eurasian Sparrowhawk, Accipiter nisus

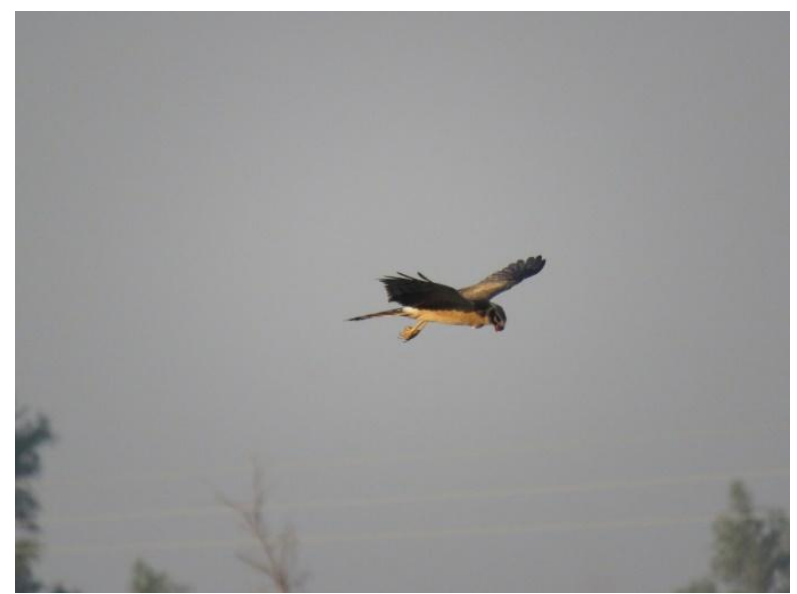

4. Pallid Harrier, Circus macrourus

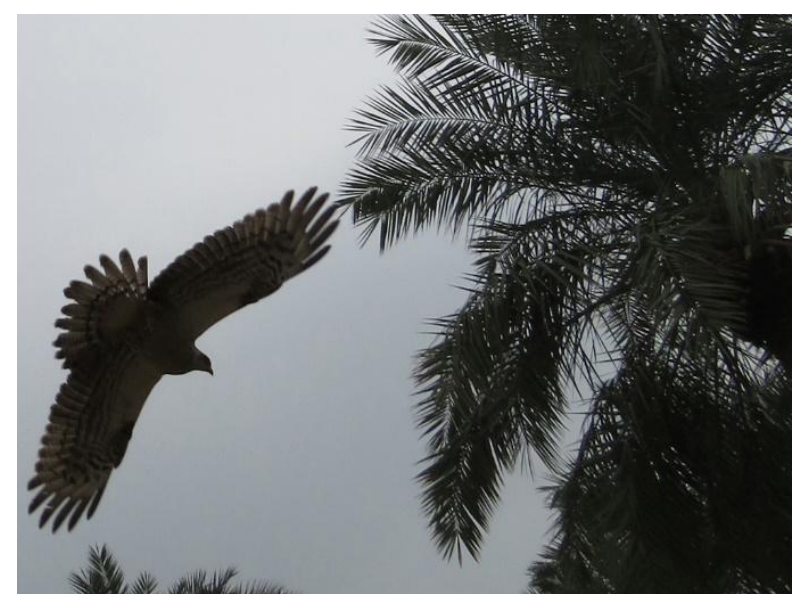

6. European Honey Buzzard, Pernis apivorus 


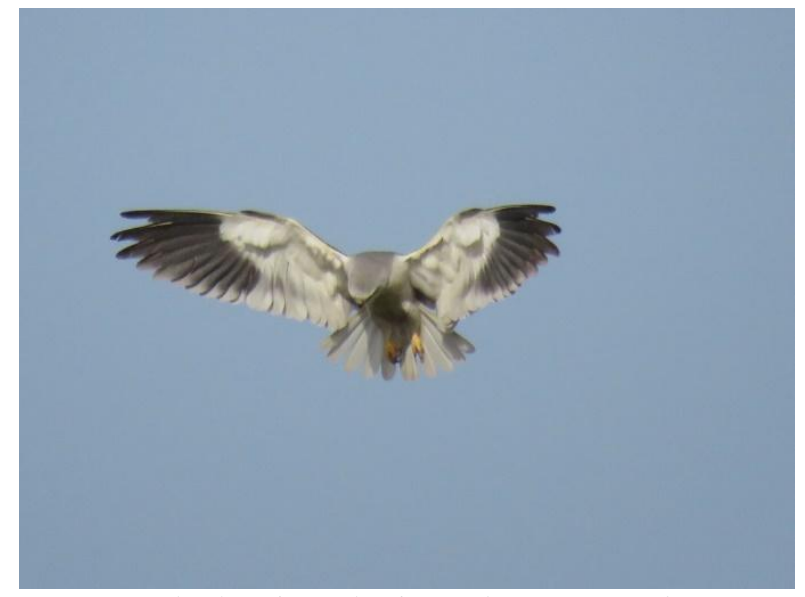

7. Black-winged Kite, Elanus caeruleus

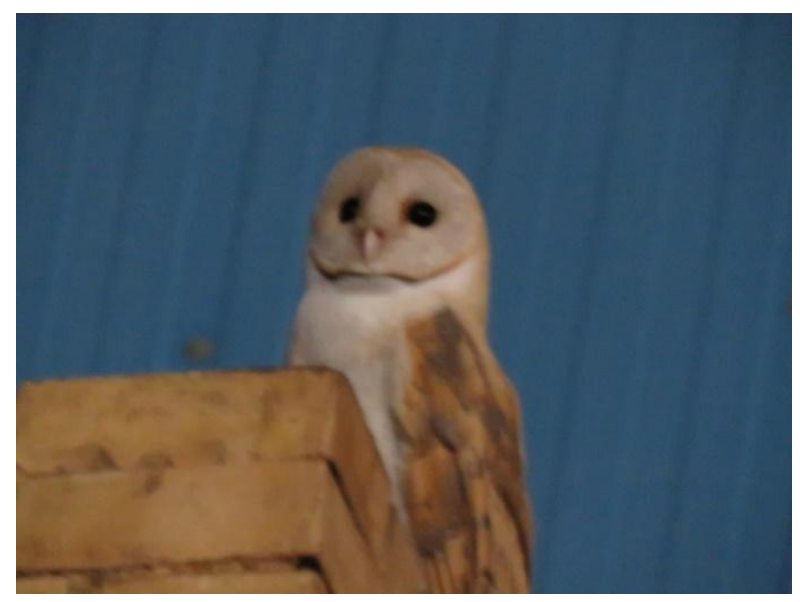

9. Western Barn Owl, Tyto alba

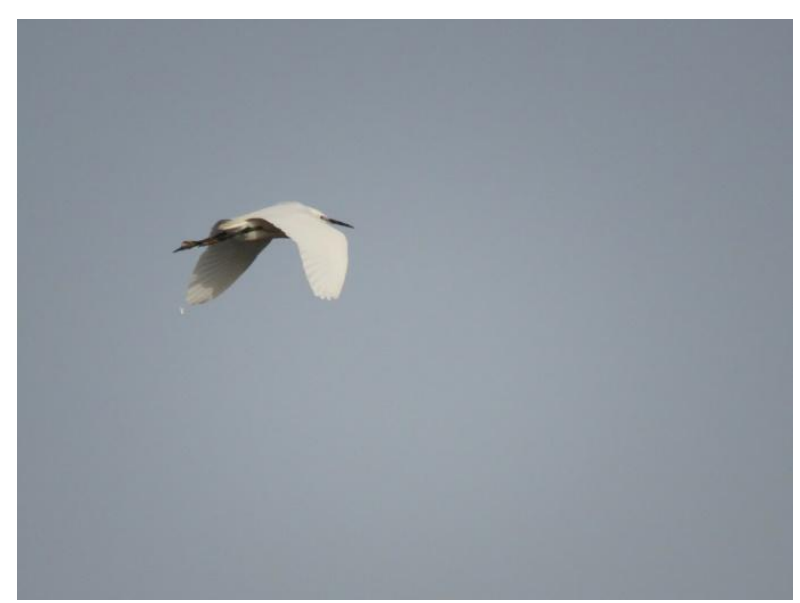

11. Little Egret, Egretta garzetta

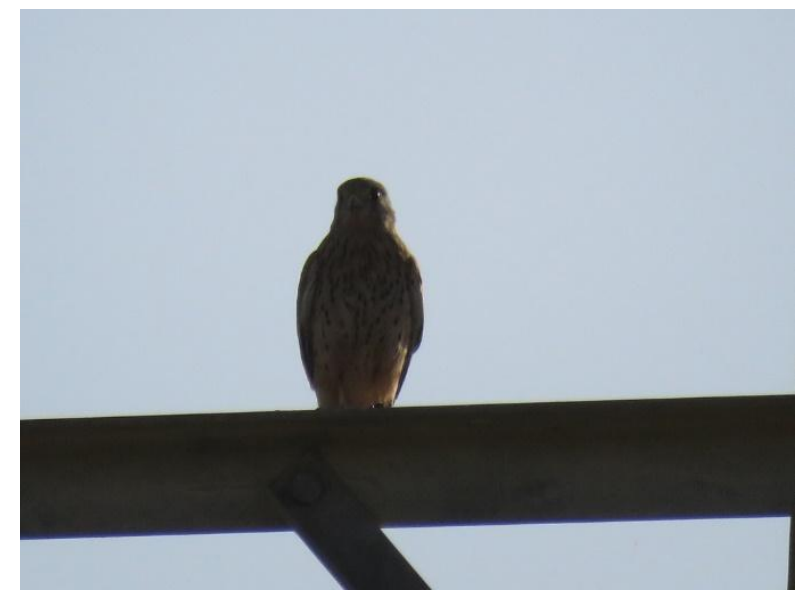

8. Common Kestrel, Falco tinnunculus

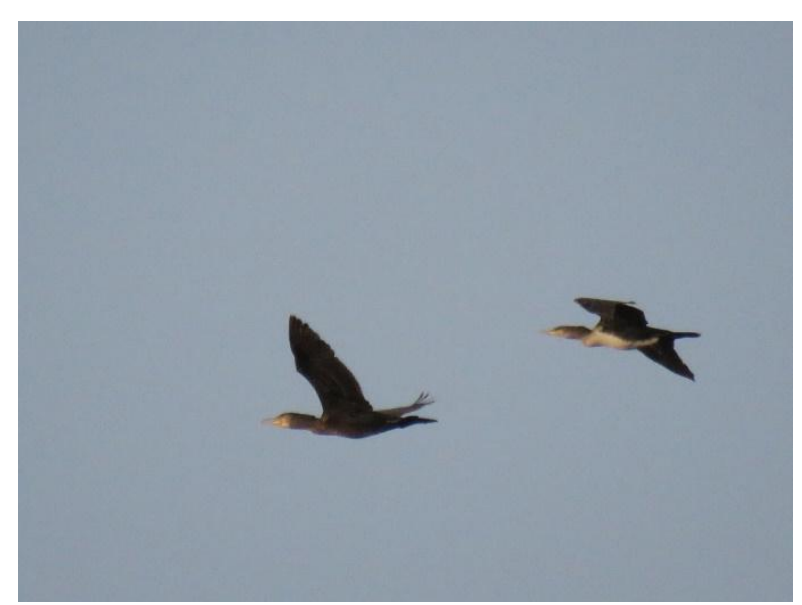

10. Great Cormorant, Phalacrocorax carbo

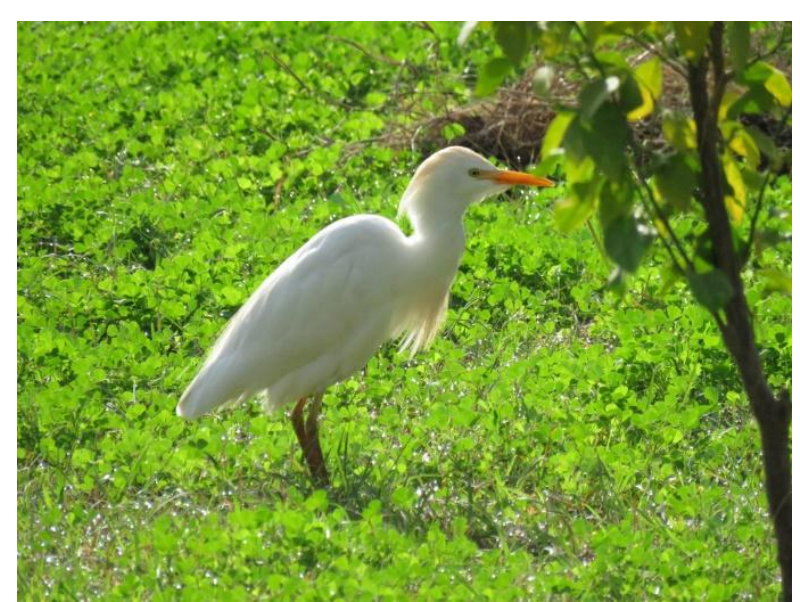

12. Western Cattle Egret, Bubulcus ibis 


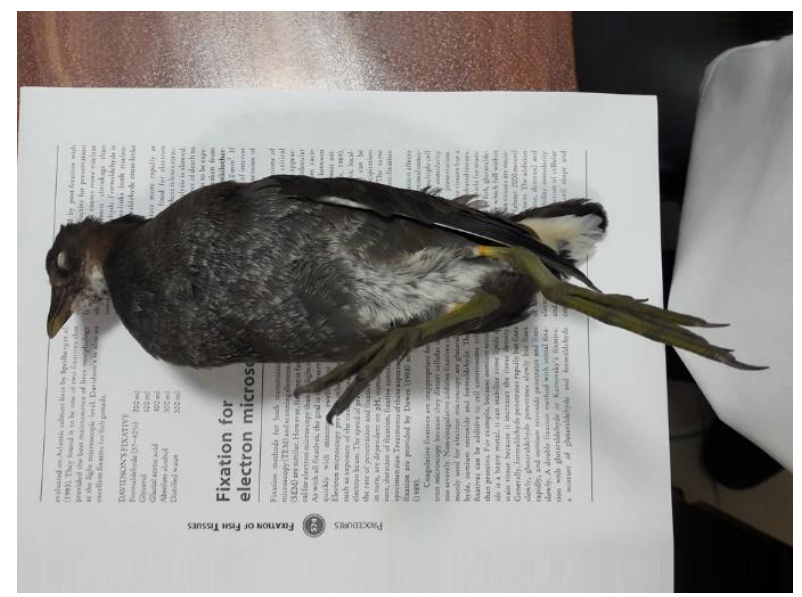

13. Common Moorhen, Gallinula chloropus

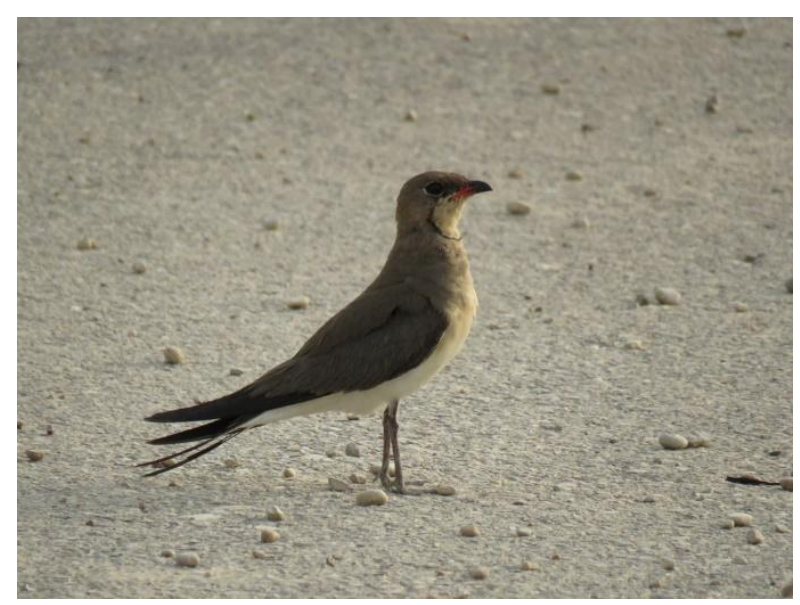

15. Collared Pratincole, Glareola pratincola

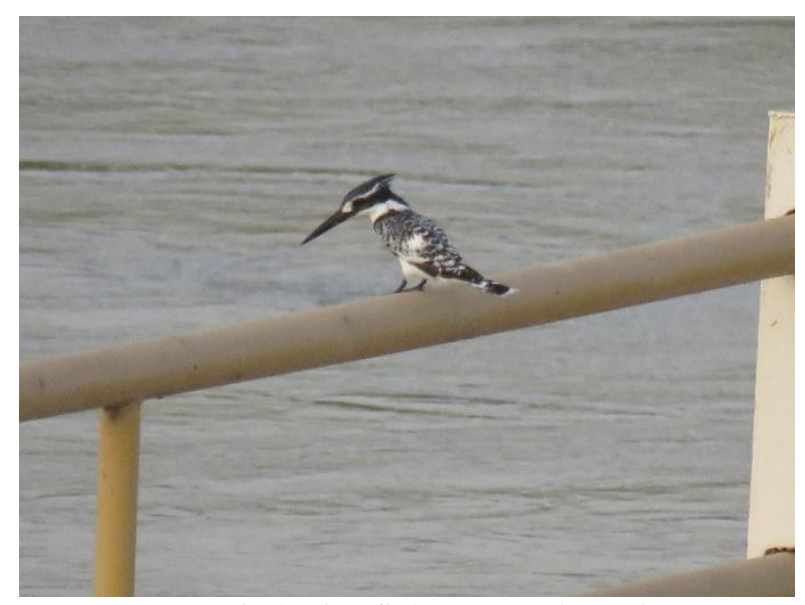

17. Pied Kingfisher, Ceryle rudis

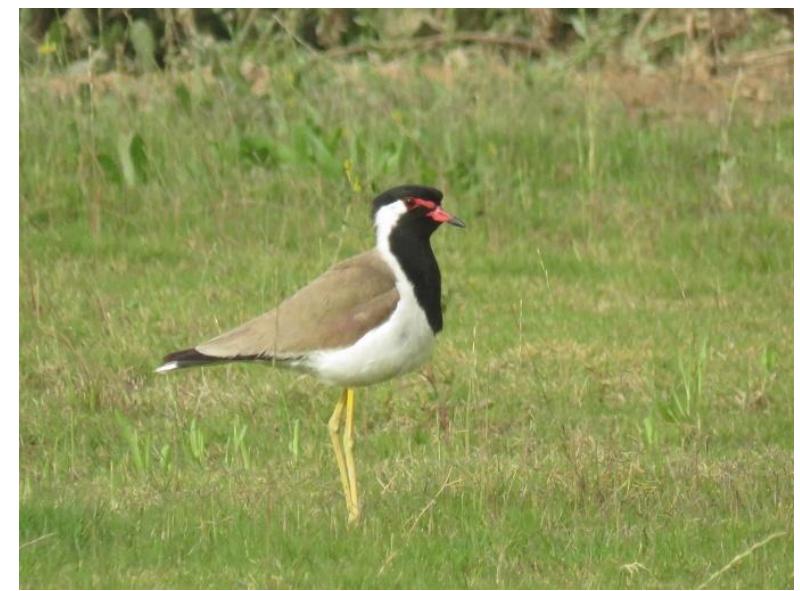

14. Red-wattled Lapwing, Vanellus indicus

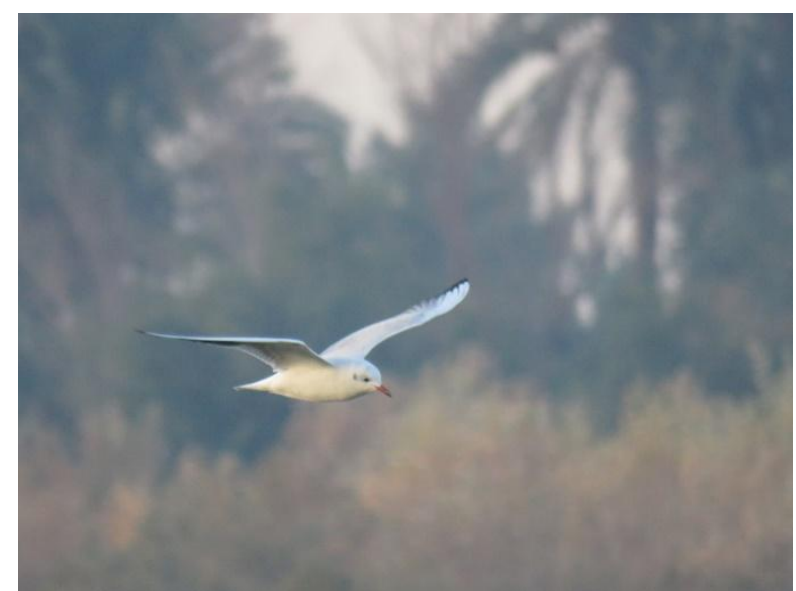

16. Black-headed Gull, Chroicocephalus ridibundus

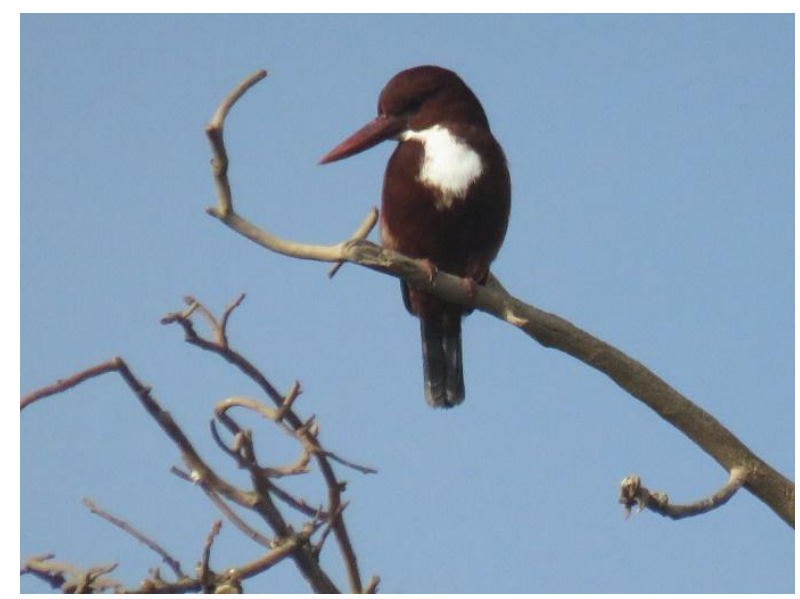

18. White-throated Kingfisher, Halcyon smyrnensis 


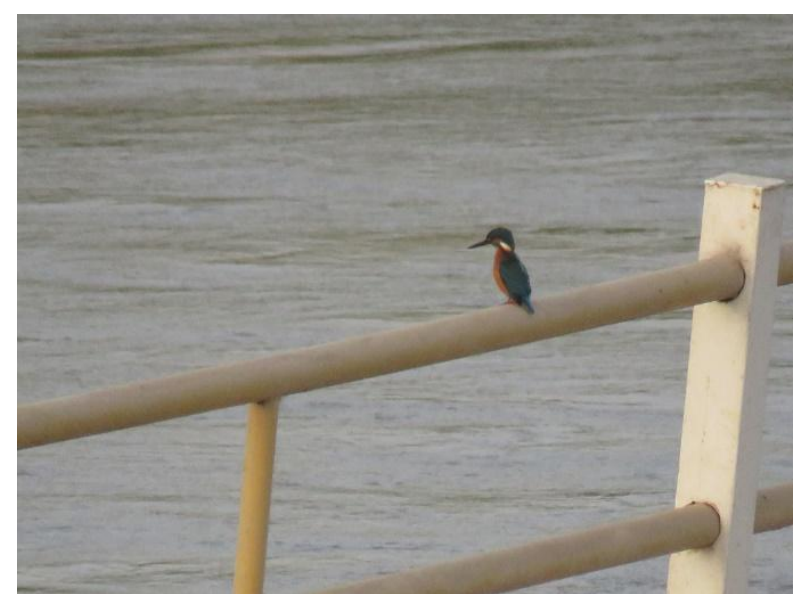

19. Common Kingfisher, Alcedo atthis

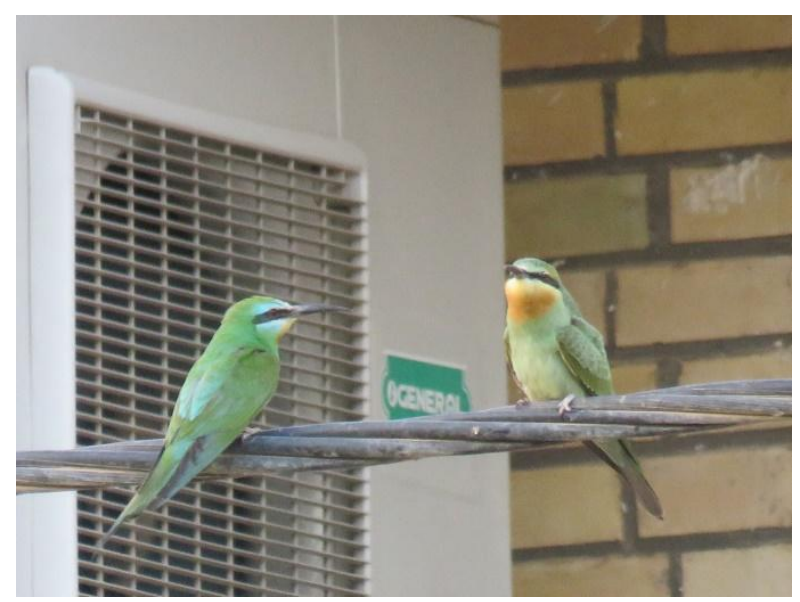

21. Blue-cheeked Bee-eater, Merops persicus

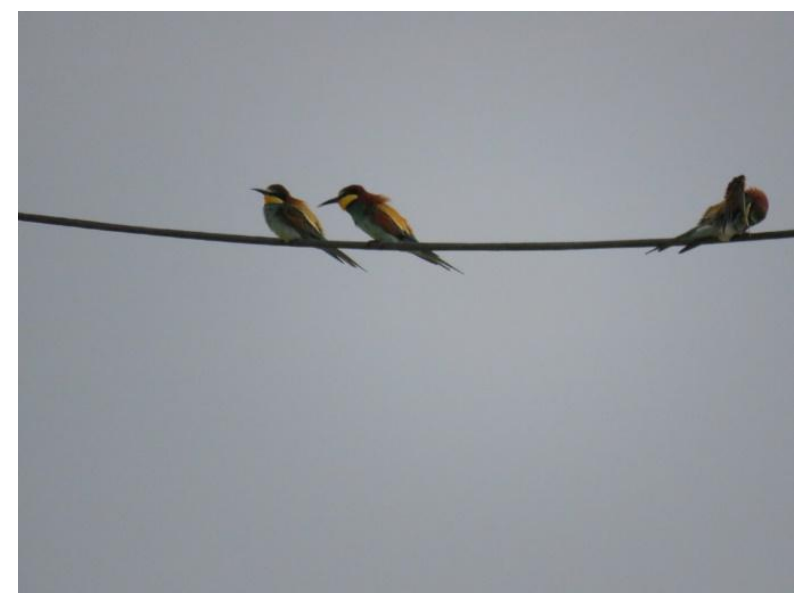

23. European Bee-eater, Merops apiaster

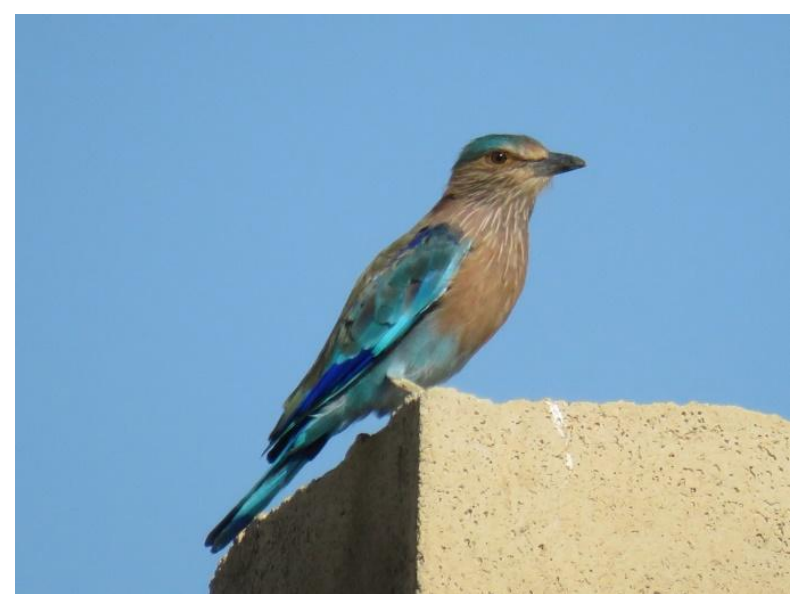

20. Indian Roller, Coracias benghalensis

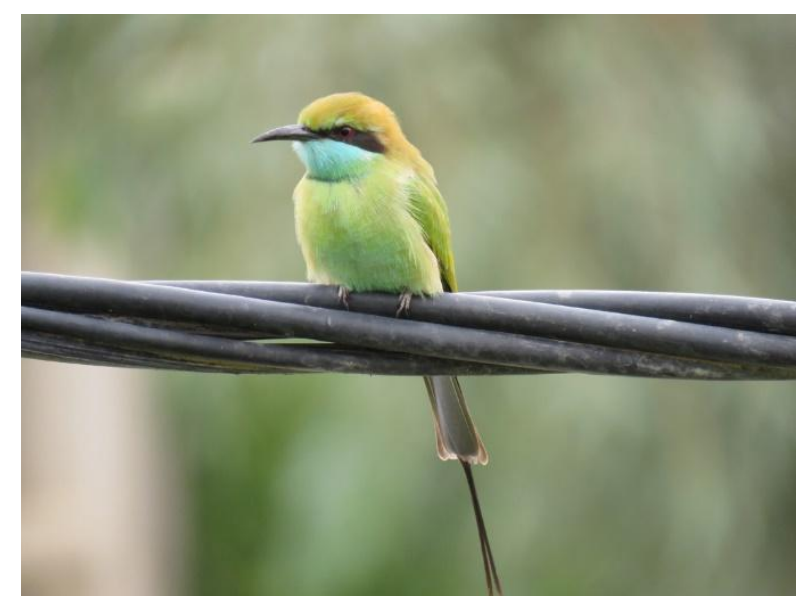

22. Green Bee-eater, Merops orientalis

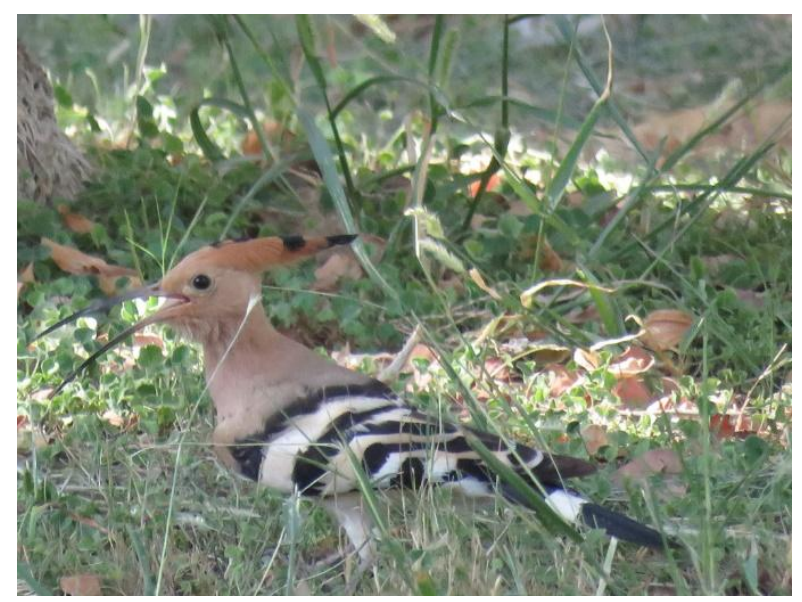

24. Eurasian Hoopoe, Upupa epops 


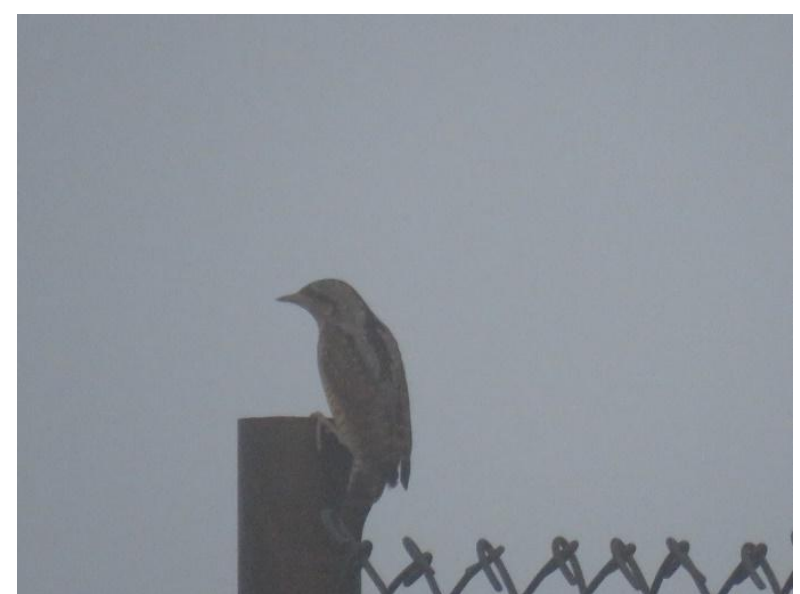

25. Eurasian Wryneck, Jynx torquilla

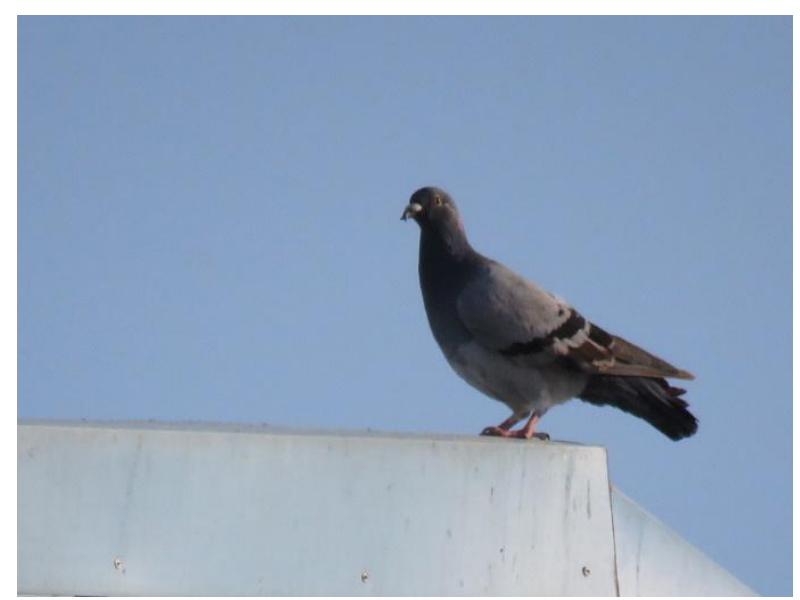

27. Rock Dove, Columba livia

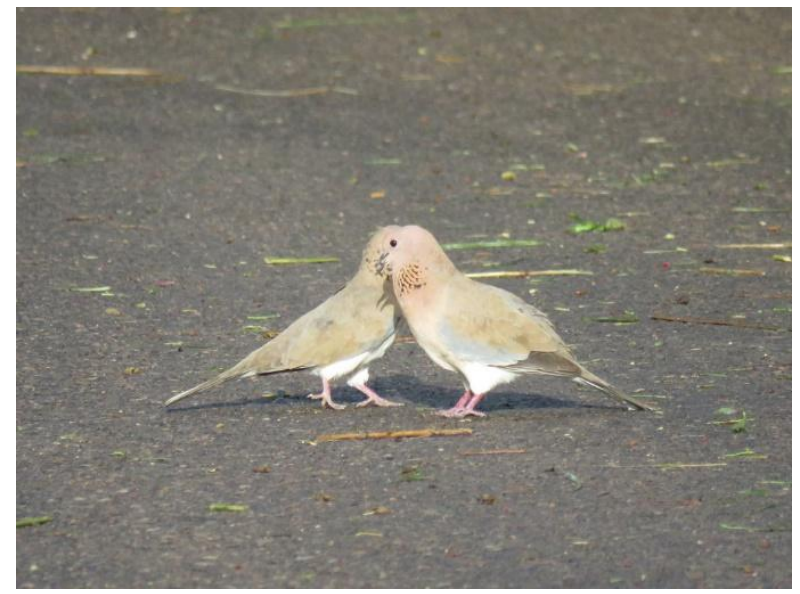

29. Laughing Dove, Spilopelia senegalensis

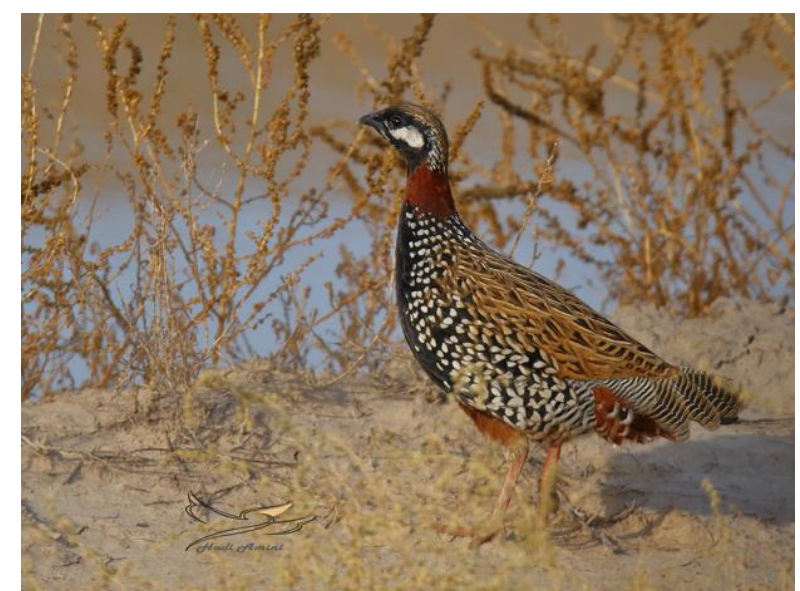

26. Black Francolin, Francolinus francolinus

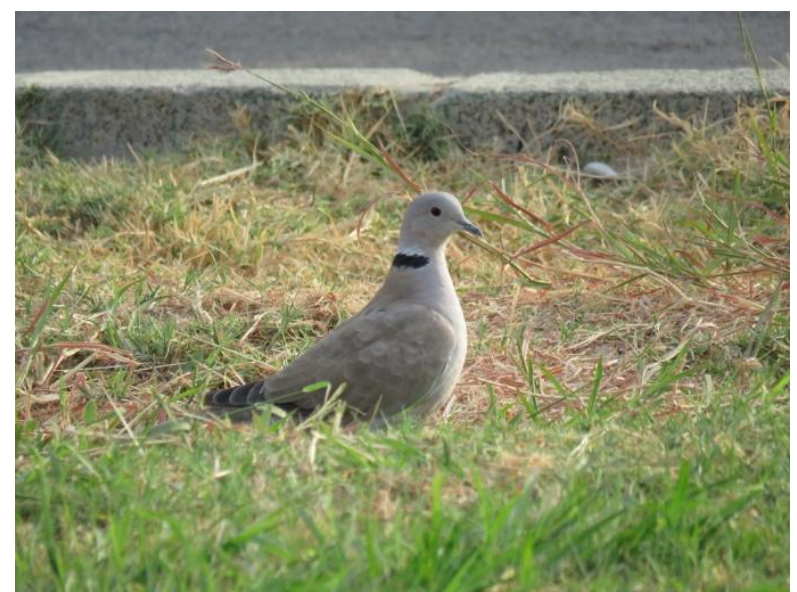

28. Eurasian Collared Dove, Streptopelia decaocto

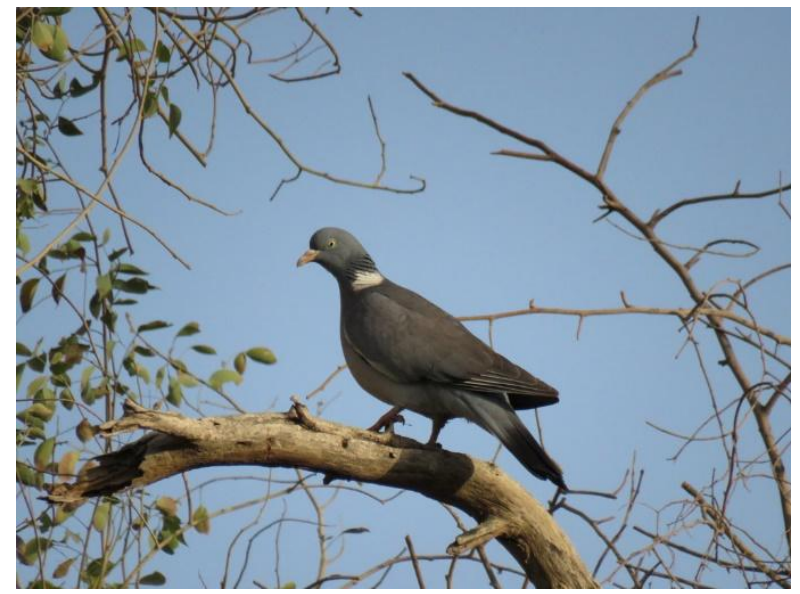

30. Common Wood Pigeon, Columba palumbus 


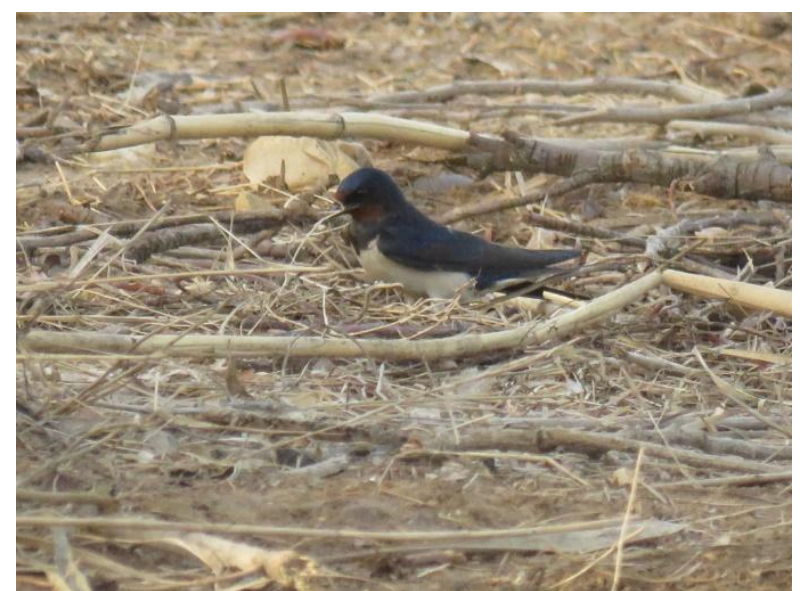

31. Barn Swallow, Hirundo rustica

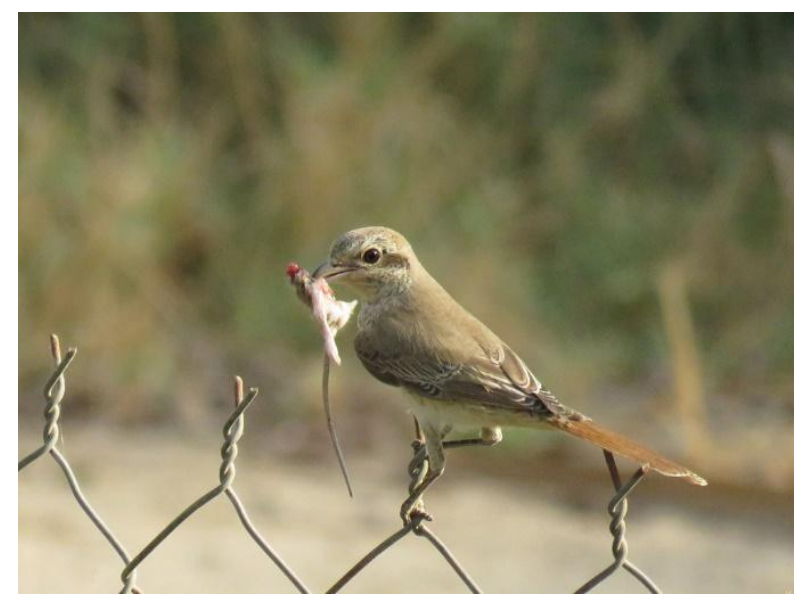

33. Isabelline Shrike, Lanius isabellinus

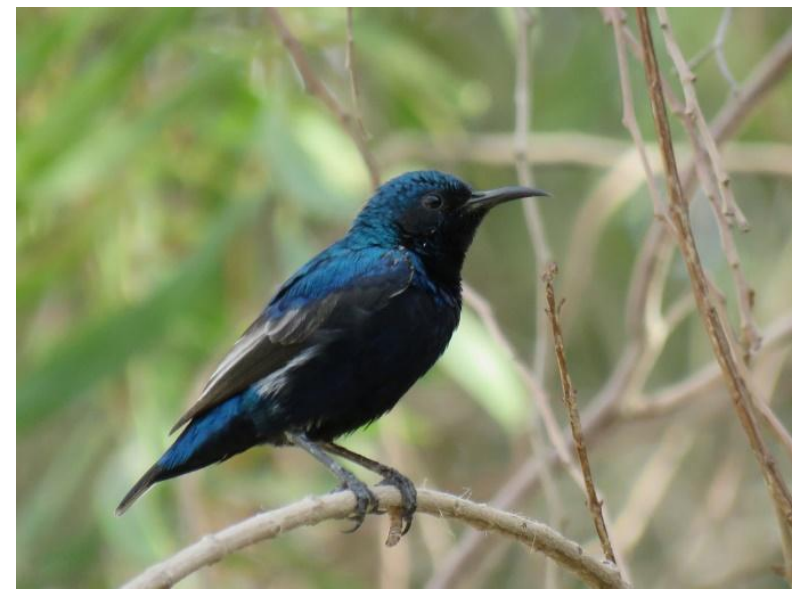

35. Purple Sunbird, Cinnyris asiaticus

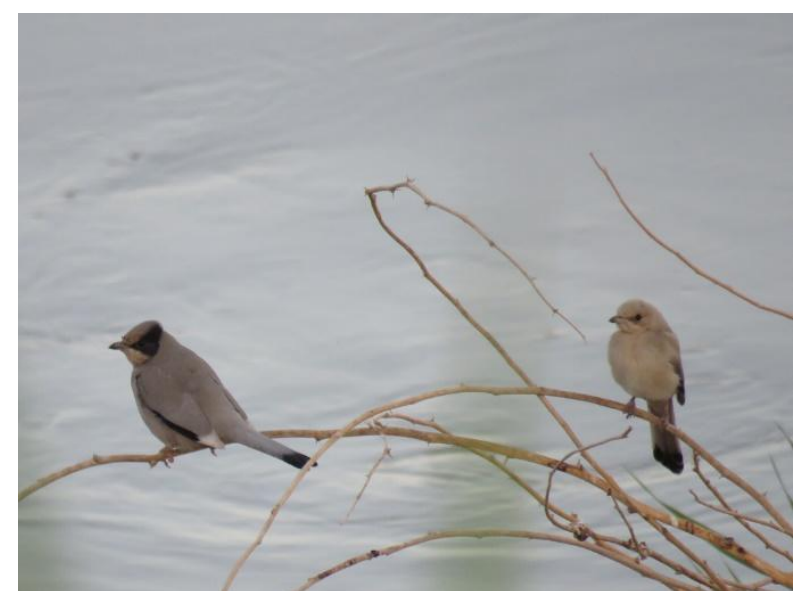

32. Grey Hypocolius, Hypocolius ampelinus

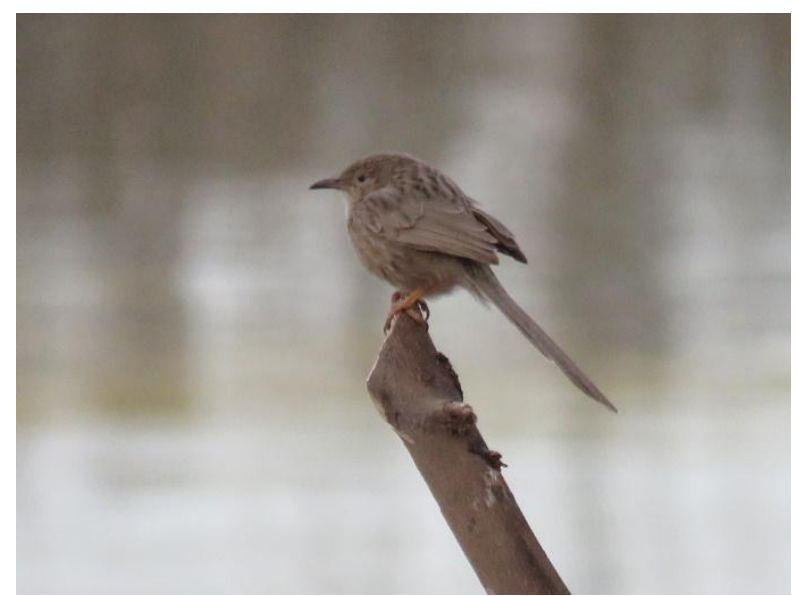

34. Afghan Babbler, Argya huttoni

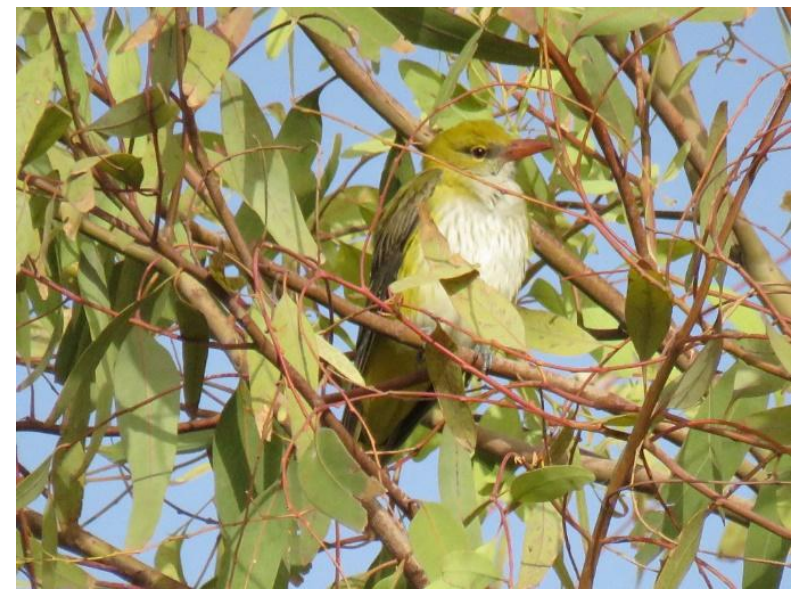

36. Eurasian Golden Oriole, Oriolus oriolus 


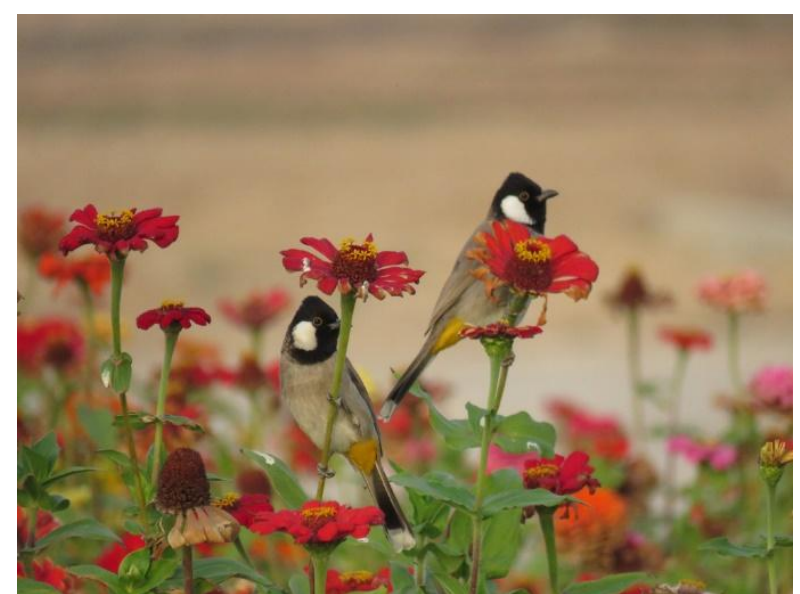

37. White-eared Bulbul, Pycnonotus leucotis

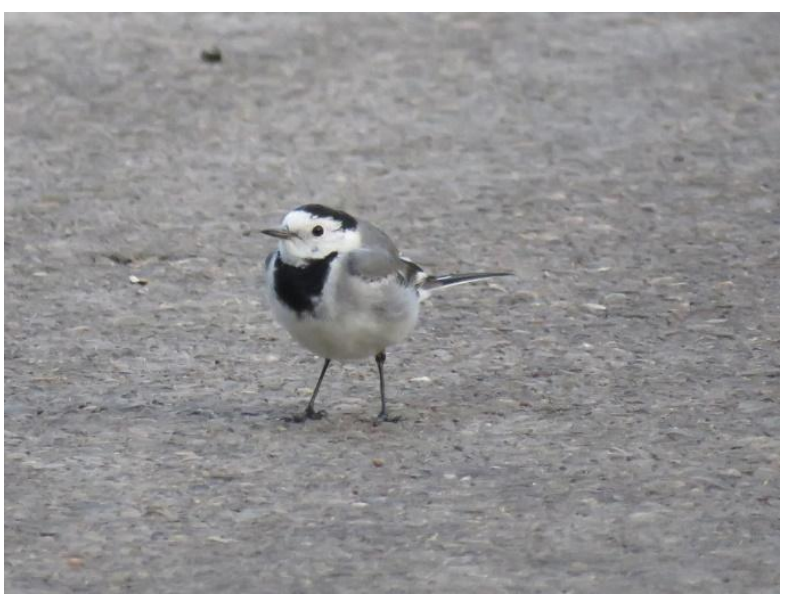

39. White Wagtail, Motacilla alba

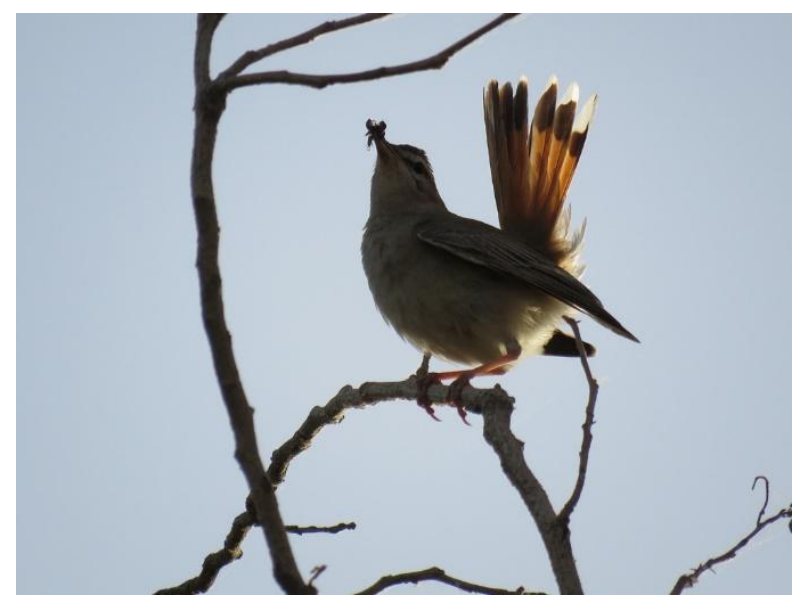

41. Rufous-tailed Scrub Robin, Cercotrichas galactotes 42. Common Nightingale, Luscinia megarhynchos

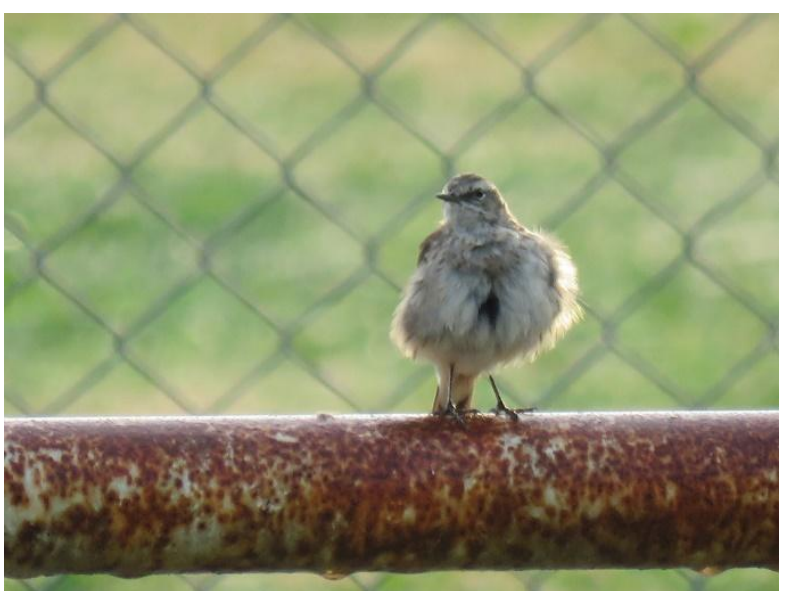

38. Water Pipit, Anthus spinoletta

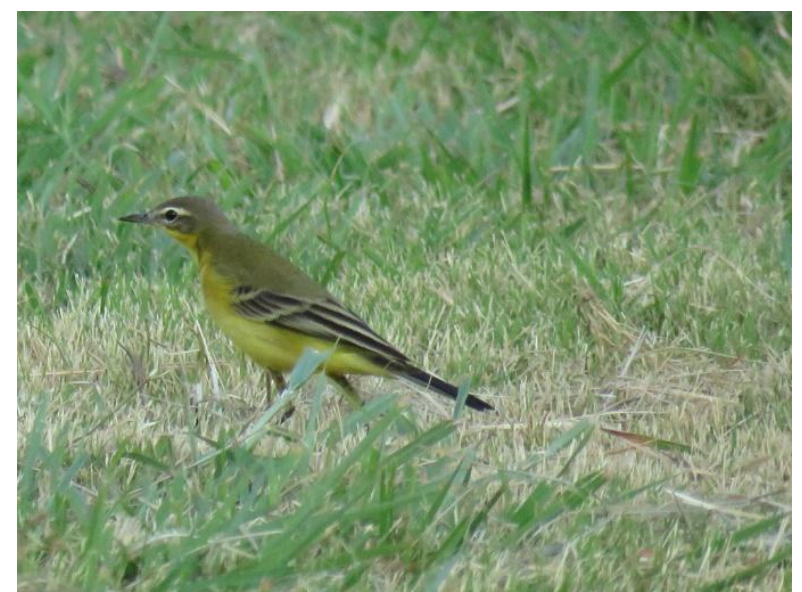

40. Western Yellow Wagtail, Motacilla flava

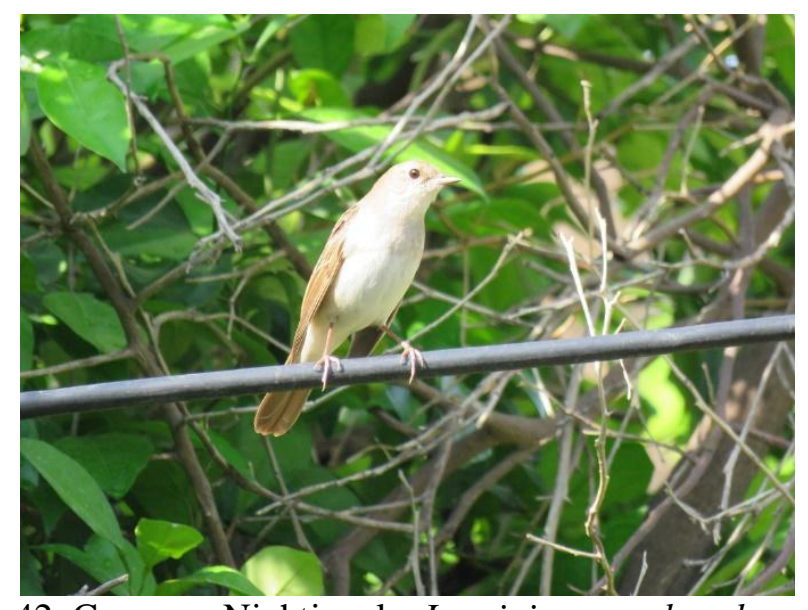




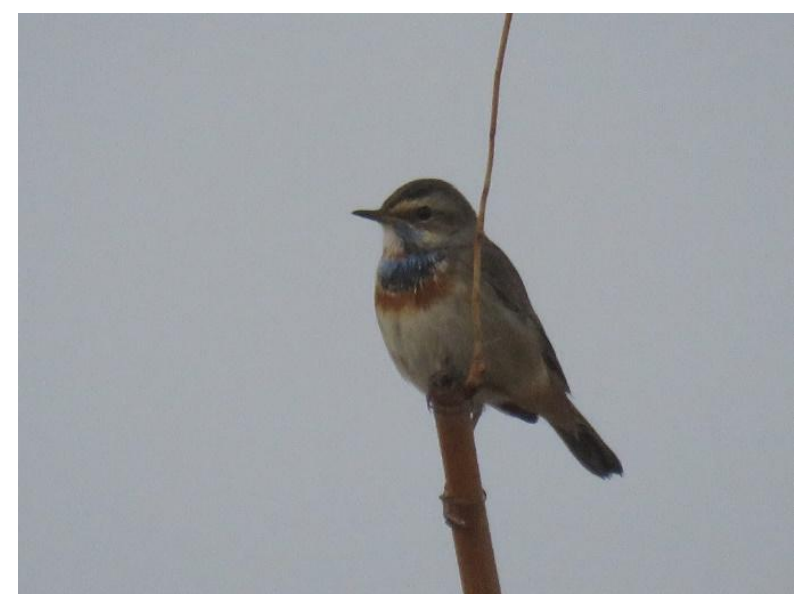

43. Bluethroat, Luscinia svecica

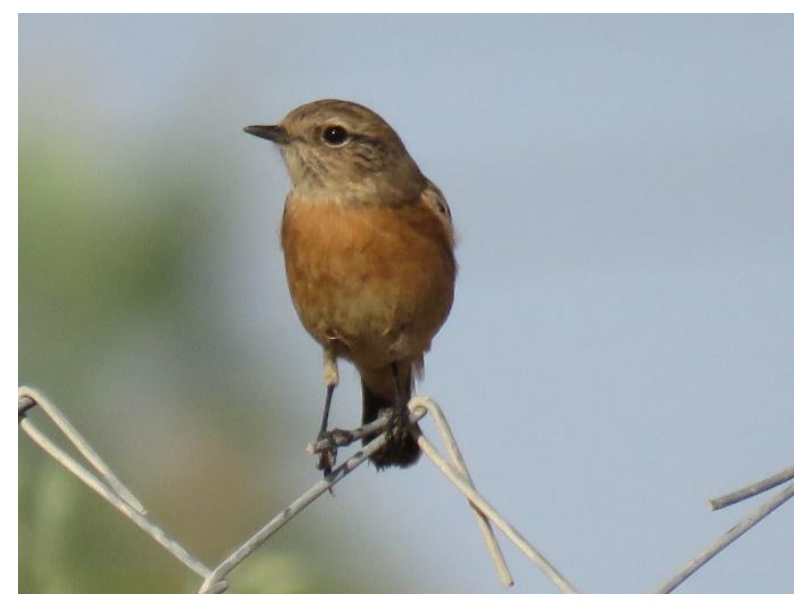

45. European Stonechat, Saxicola rubicola

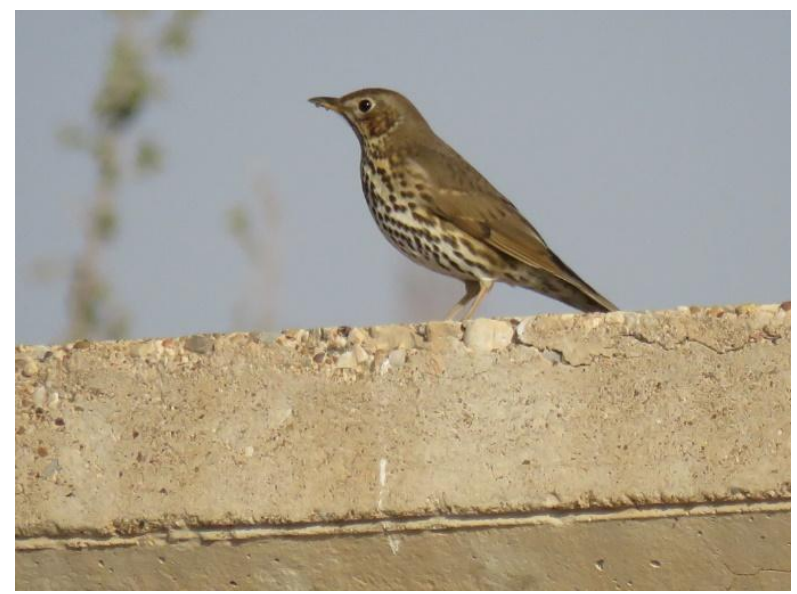

47. Song Thrush, Turdus philomelos

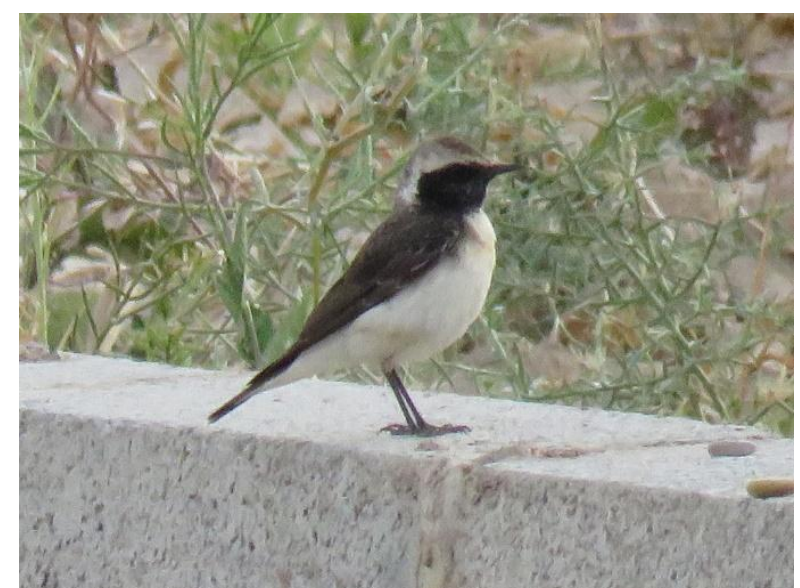

44. Pied Wheatear, Oenanthe pleschanka

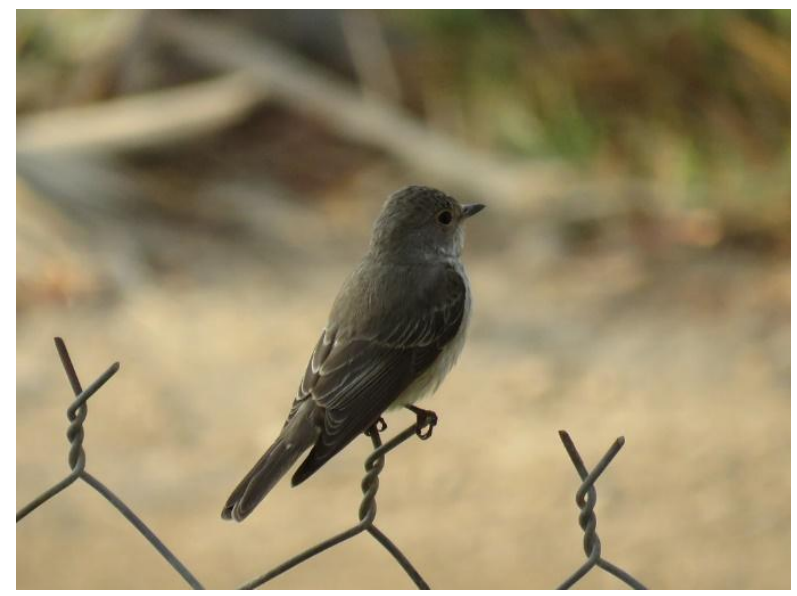

46. Spotted Flycatcher, Muscicapa striata

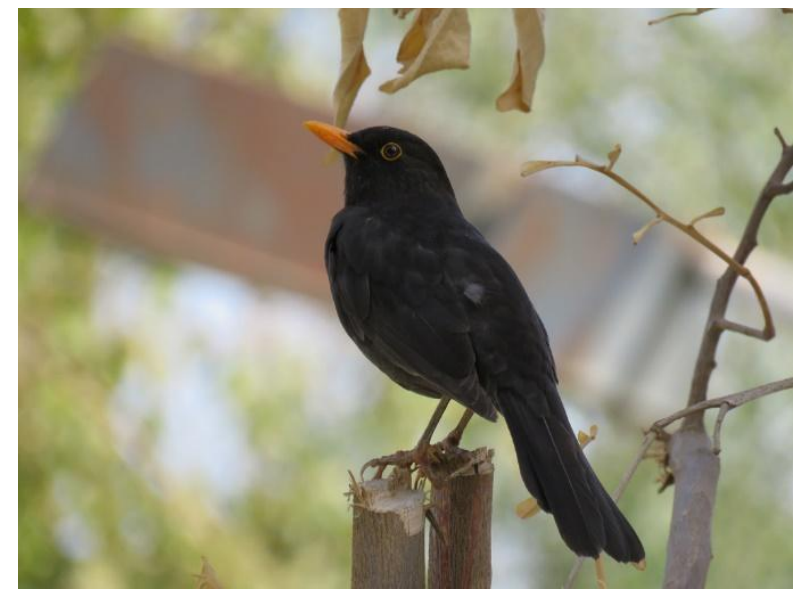

48. Common Blackbird, Turdus merula 


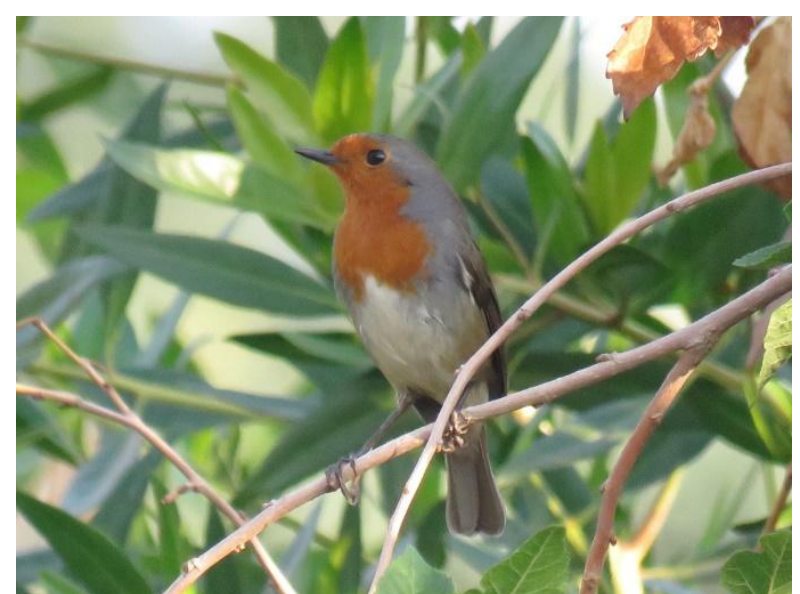

49. European Robin, Erithacus rubecula

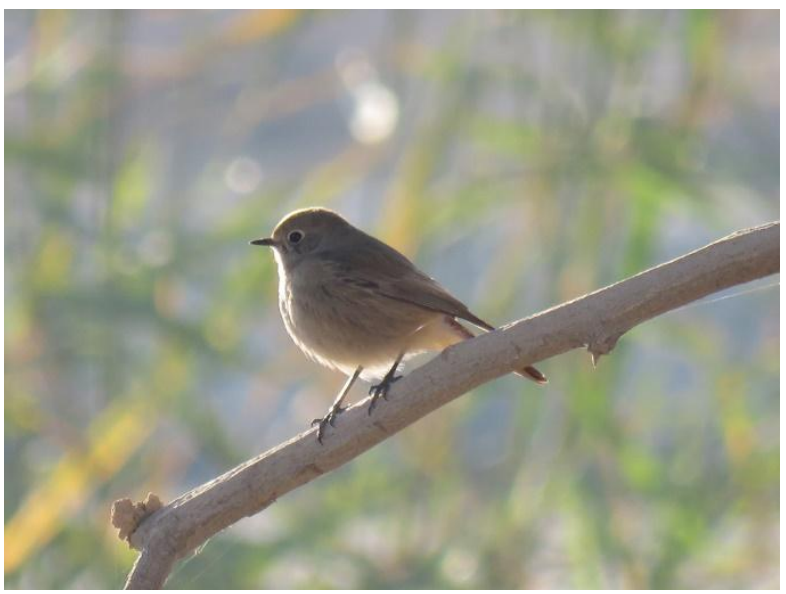

51. Common Redstart, Phoenicurus phoenicurus

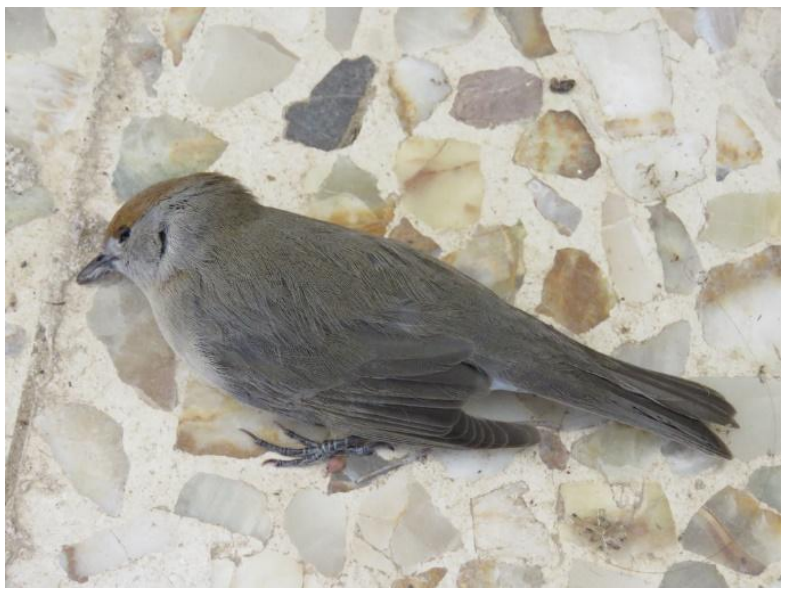

53. Eurasian Blackcap, Sylvia atricapilla

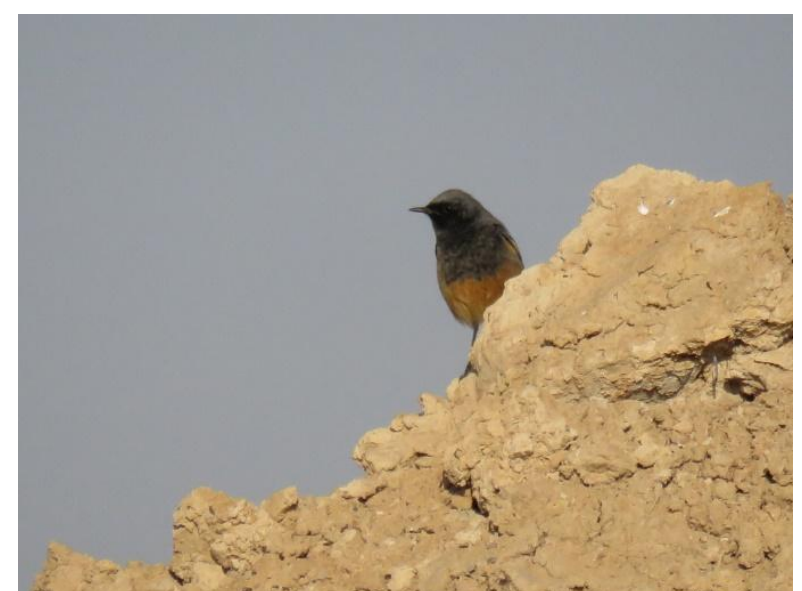

50. Black Redstart, Phoenicurus ochruros

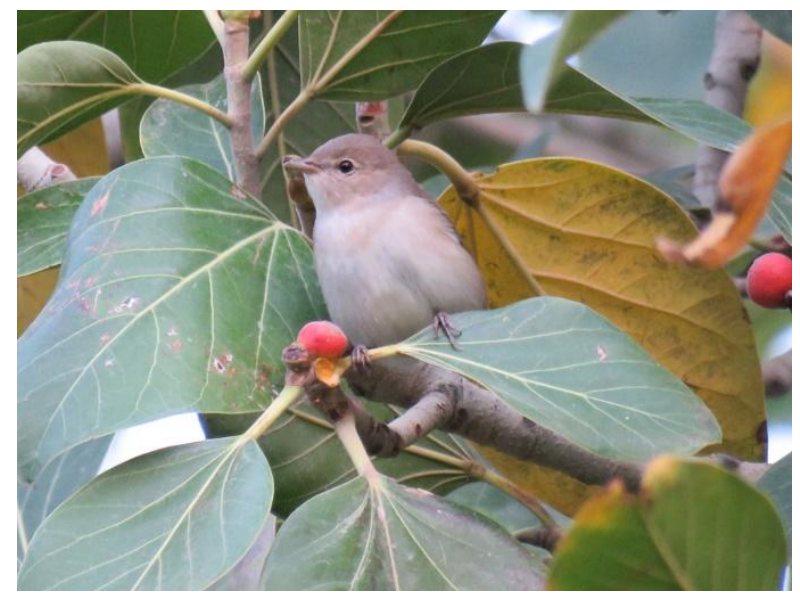

52. Garden Warbler, Sylvia borin

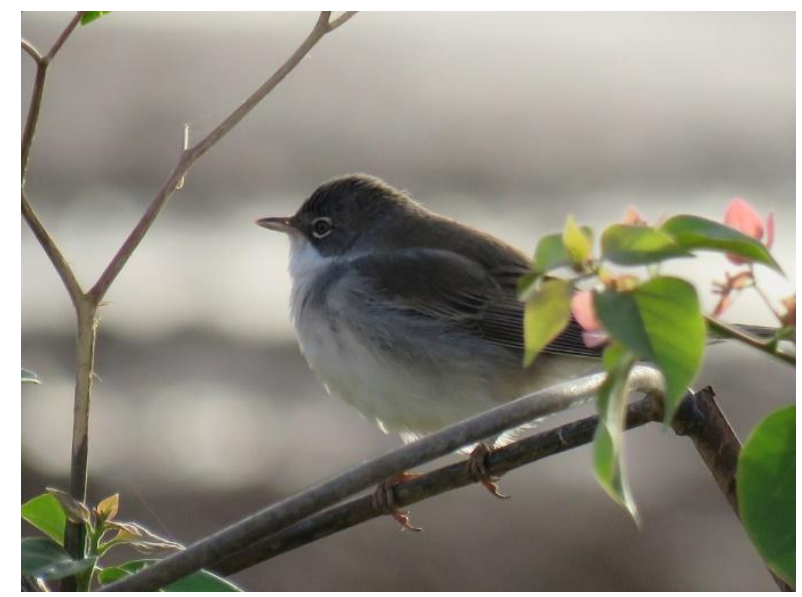

54. Common Whitethroat, Sylvia communis 


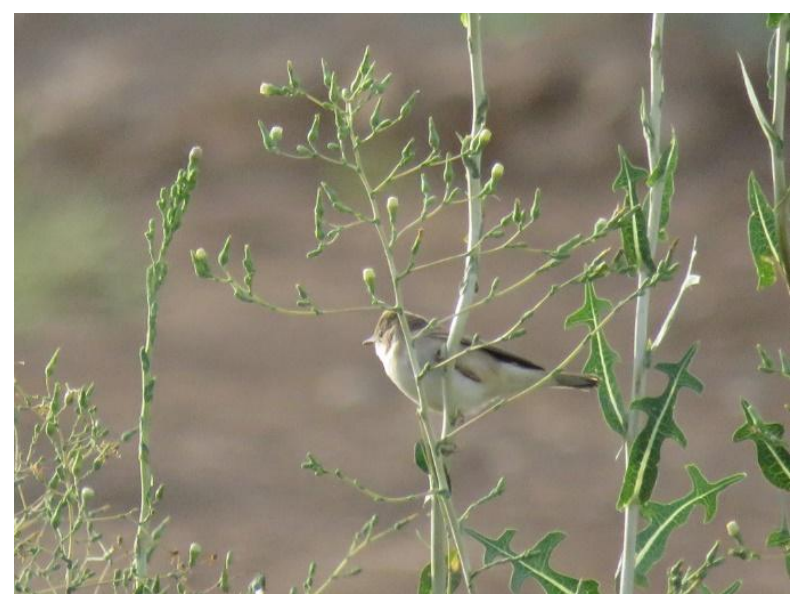

55. Desert Whitethroat, Sylvia minula

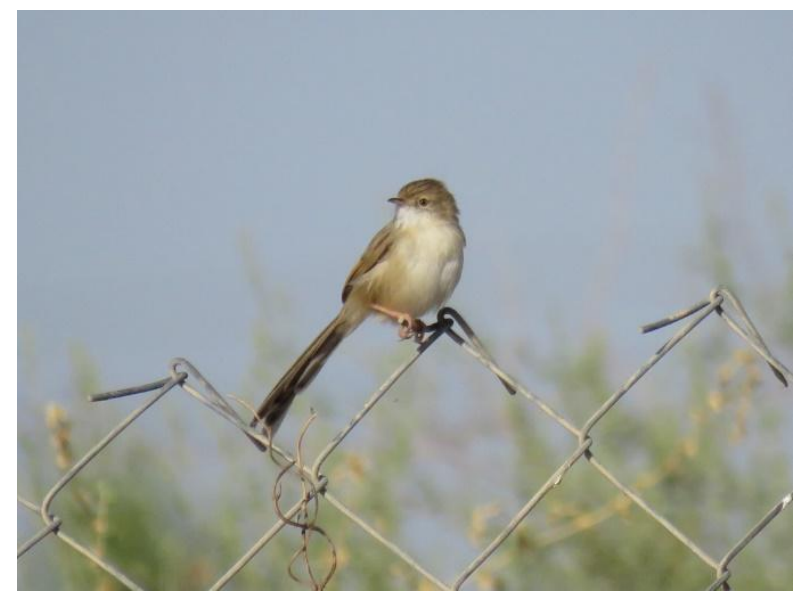

57. Graceful Prinia, Prinia gracilis

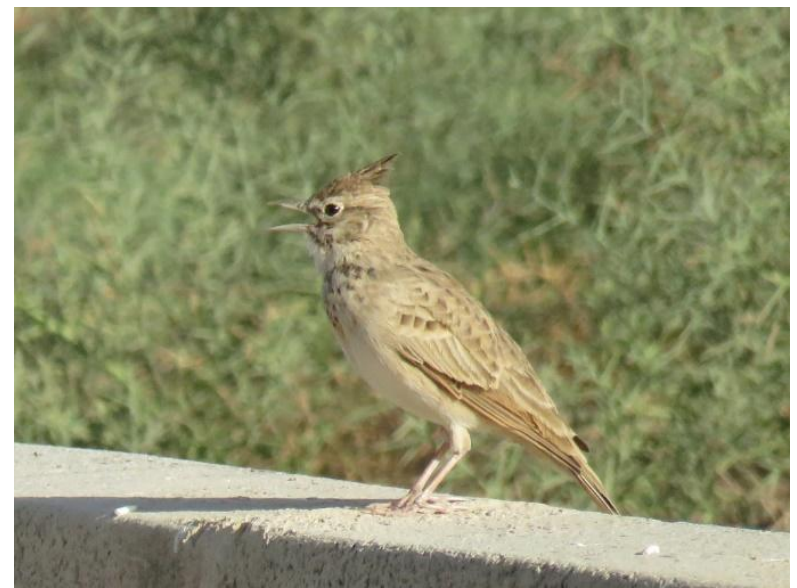

59. Crested Lark, Galerida cristata

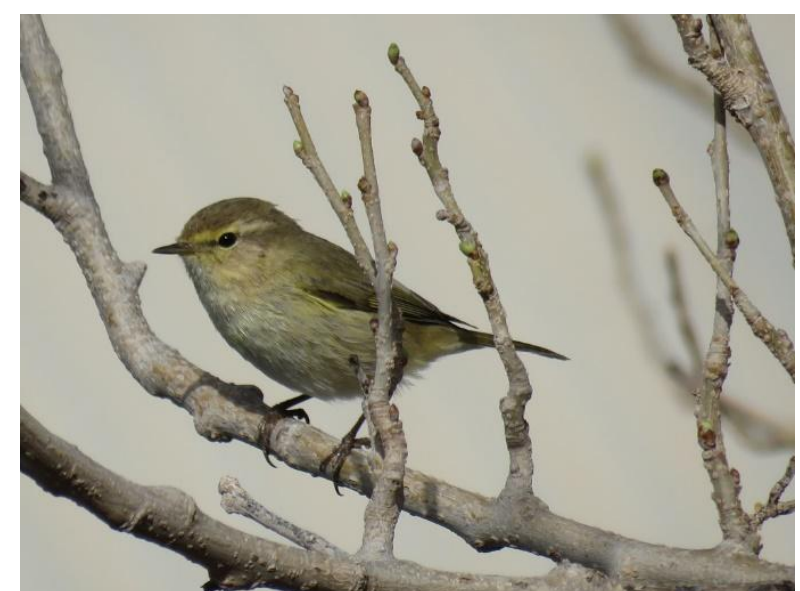

56. Common Chiffchaff, Phylloscopus collybita

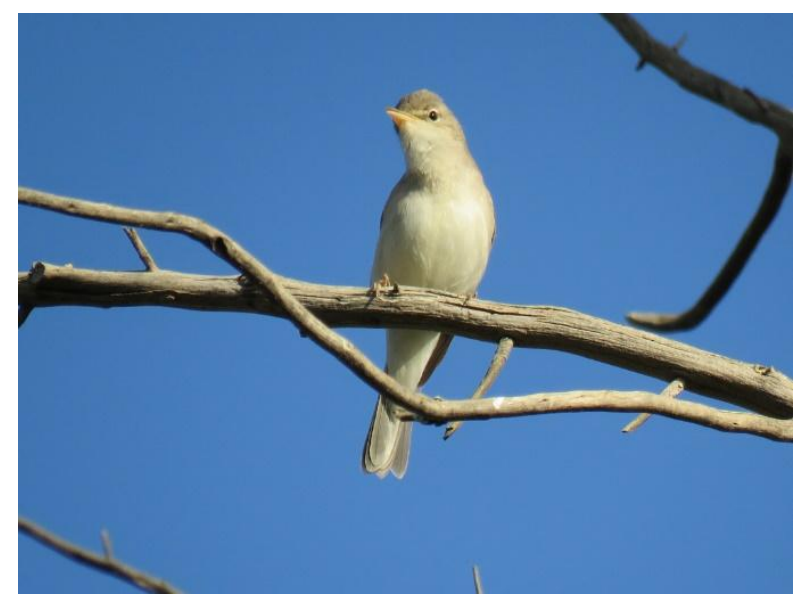

58. Eastern Olivaceous Warbler, Iduna pallida

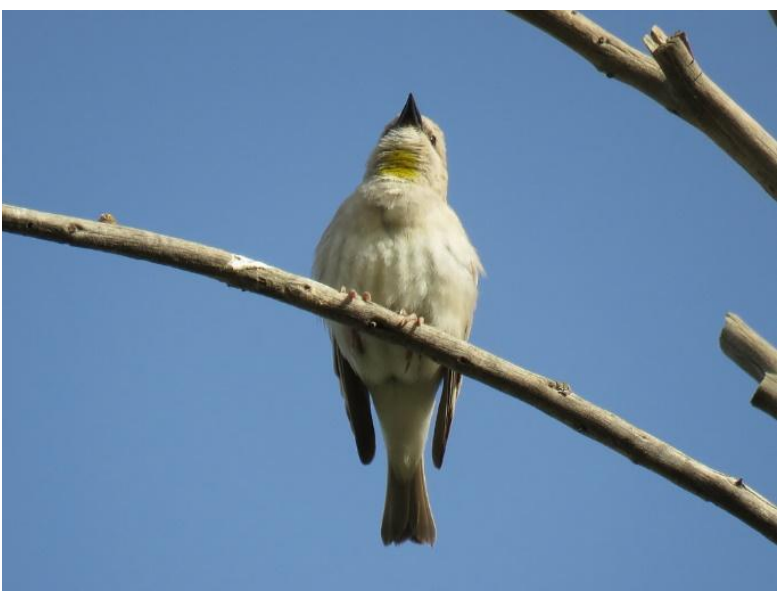

60. Yellow-throated Sparrow, Gymnoris xanthocollis 


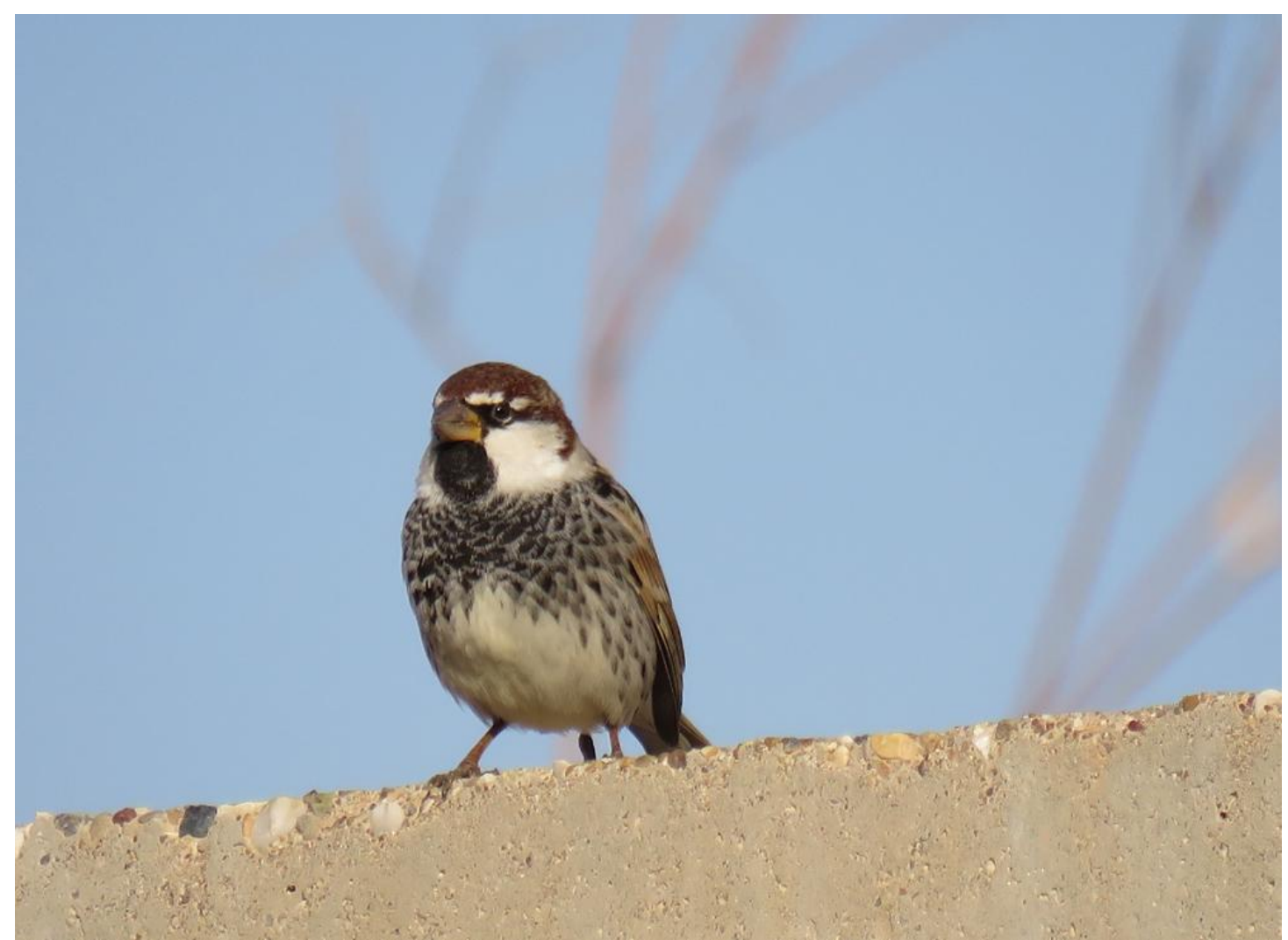

61. Spanish Sparrow, Passer hispaniolensis

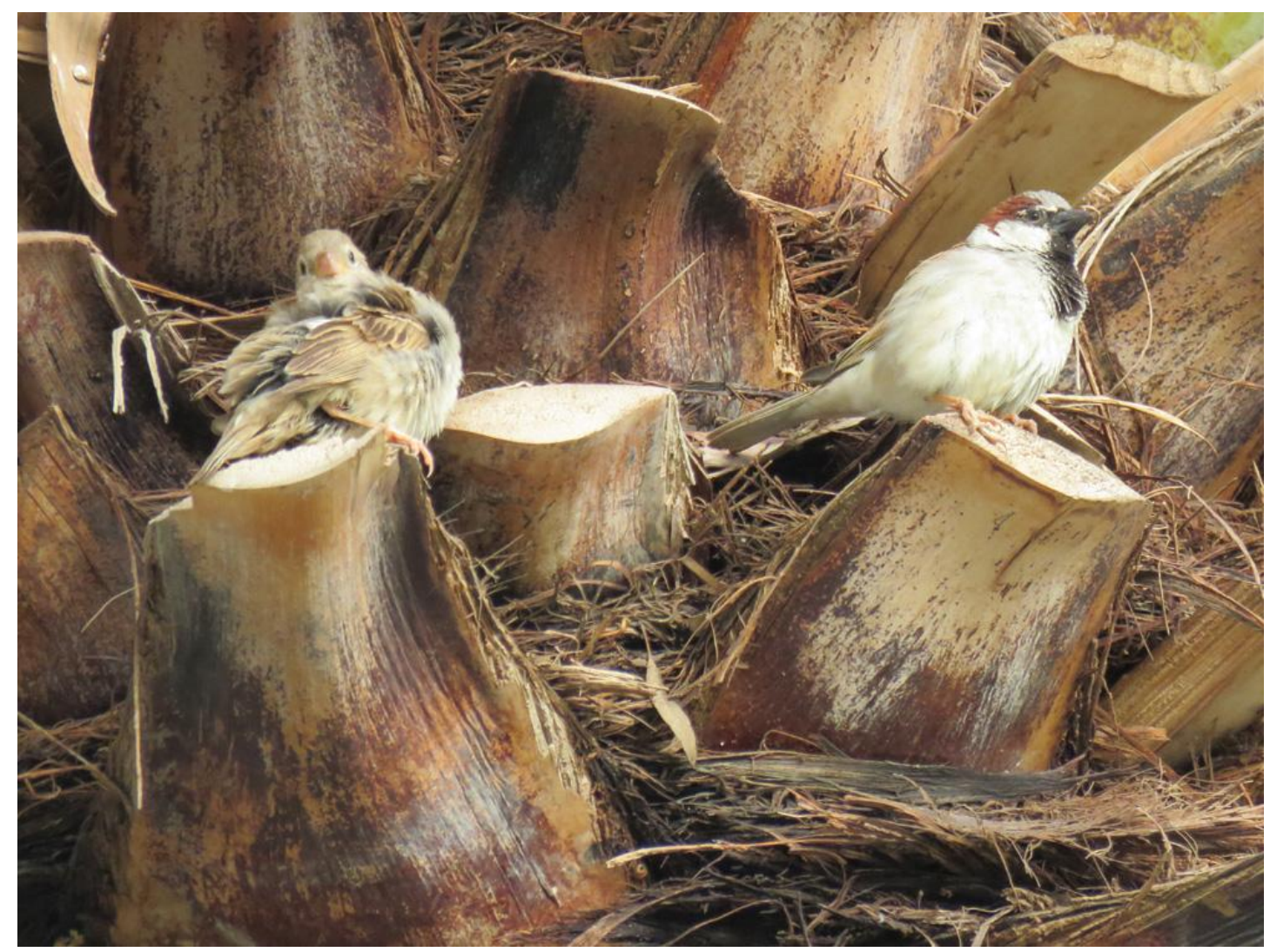

62. House Sparrow, Passer domesticus 